\title{
Mineral properties, microbes, transport, and plant-input profiles control vertical distribution and age of soil carbon stocks
}

\author{
D. Dwivedi ${ }^{1 *}$, W.J. Riley ${ }^{1}$, M.S. Torn ${ }^{1}$, N. Spycher ${ }^{1}$, F.M. Maggi ${ }^{2}$, J.Y. Tang ${ }^{1}$ \\ ${ }^{1}$ Earth and Environmental Sciences Area, Lawrence Berkeley National Laboratory, \\ Berkeley, CA 94720 \\ ${ }^{2}$ School of Civil Engineering, The University of Sydney, Sydney 2006, NSW, Australia
}

Submitted to

Soil Biology \& Biochemistry

November 23, 2017

*Corresponding Author: Dipankar Dwivedi

Earth and Environmental Sciences Area, Lawrence Berkeley National Laboratory, Berkeley, California, USA, 94720-0001, Email: DDwivedi@lbl.gov, ph. (+1) 510-4864005, Fax: 510-486-5686 


\title{
Mineral properties, microbes, transport, and plant-input profiles control vertical distribution and age of soil carbon stocks
}

\author{
D. Dwivedi ${ }^{1}$, W.J. Riley ${ }^{1}$, M.S. Torn ${ }^{1}$, N. Spycher ${ }^{1}$, F.M. Maggi ${ }^{2}$, J.Y. Tang ${ }^{1}$ \\ ${ }^{1}$ Earth and Environmental Sciences Area, Lawrence Berkeley National Laboratory, \\ Berkeley, CA 94720 \\ ${ }^{2}$ School of Civil Engineering, The University of Sydney, Sydney 2006, NSW, Australia
}

\begin{abstract}
The role of organo-mineral interactions, microbial dynamics, and vertical plant input profiles are hypothesized to be important in controlling soil organic matter (SOM) stocks and dynamics. To test this hypothesis, we enhanced and applied a model (Biotic and Abiotic Model of SOM - BAMS1) that represents microbial dynamics and organomineral interactions integrated with a multiphase reactive transport solver for variably saturated porous media. The model represents aqueous chemistry, aqueous advection and diffusion, gaseous diffusion, sorption processes, bacterial and fungal activity, and archetypal monomer- and polymer-carbon substrate groups, including dead cell wall material. This model structure is fundamentally different, and produces different SOM dynamics, than the pseudo-first order relationships that are used in most site- and globalscale terrestrial SOM models. We simulated two grasslands, a seven-site chronosequence $(\sim 3.9-240 \mathrm{Ky})$ in Northern California, and a Russian Chernozem site where soils were sampled 100 years apart. We calibrated the model's vertically-resolved soil bulk specific surface area (SBSSA) using observed bulk SOM content, and then tested the model against observed $\Delta^{14} \mathrm{C}$ profiles. The modeled microbial processes, organo-mineral
\end{abstract}


interactions, and vertical aqueous transport produced realistic vertically-resolved predictions of bulk SOM content, $\Delta{ }^{14} \mathrm{C}$ values of SOM, lignin content, and fungi-toaerobic bacteria biomass ratios. Using sensitivity analyses, we found that vertical carbon

input profiles were important controls over the $\Delta{ }^{14} \mathrm{C}$ depth distribution. Shallower carbon input profiles lead to older carbon at depth. In addition, the SBSSA was the dominant control over the magnitude and vertical distribution of SOM stocks. The findings of this study demonstrate the value of explicitly incorporating microbial activity, sorption, and vertical transport into land models to predict SOM dynamics.

KEYWORD: BAMS1; SOM DYNAMICS; Organo-mineral interactions 


\section{Introduction}

Global soil carbon stocks are approximately three times as large as the carbon stocks in either the atmosphere or terrestrial vegetation (Schmidt et al., 2011). This carbon may be vulnerable to decomposition and release to the atmosphere due to environmental changes (e.g., thermokarst, warming). Predicting long-term changes in soil carbon storage and feedbacks with climate change requires understanding how soil organic matter (SOM) dynamics vary vertically within the soil column (Schmidt et al., 2011; Koven et al., 2013; Riley et al., 2014).

Mineral surfaces interact chemically with dissolved organic carbon (DOC) and help stabilize soil organic carbon (SOC) (Greenland, 1971; Jagadamma et al., 2012; Lutzow et al., 2006; Sibanda and Young, 1986; Sollins et al., 1996; Trumbore, 1997). The proportion and persistence of organic compounds that are at least partially protected against decomposition on soil mineral surfaces depends on several factors, including the chemical composition of the substrate, texture, mineralogy, $\mathrm{pH}$, temperature, soil aggregates, and hydrologic transport (Conant et al., 2011; Gjettermann et al., 2008; Jardine et al., 1989, 1990; Kalbitz et al., 2003; Kothawala and Moore, 2009; Moore and Turunen, 2004; Six et al., 2004). Organo-mineral interactions may be especially important below the active root zone (Ahrens et al., 2015; Kalbitz et al., 2000, 2003; Masiello et al., 2004; Sanderman et al., 2008; Torn et al., 1997a) and in deeper horizons with iron, aluminum, and clay-rich minerals (Jardine et al., 1989, 1990, 2006; Kothawala et al., 2009). These findings may partially explain the observed wide range of SOM residence times among sites, but it is presumable that interactions with mineral surfaces introduce more complexity than currently represented in terrestrial carbon cycle models. 
Most land models apply a pseudo-first-order representation for soil organic matter (SOM) dynamics, with several SOM 'pools' with explicit turnover times that are dynamically affected by temperature and moisture (e.g., Century (Parton et al., 1987, 2010), RothC (Jenkinson and Coleman, 2008)). Some of these models also represent the role of mineral protection by modifying the proportional transfers between pools and the explicit turnover times as a function of mineralogy, usually clay content (Jenkinson and Coleman, 2008; Parton et al., 2010). To our knowledge, organo-mineral interactions are represented explicitly in only one global land model (Sulman et al., 2014). Sulman et al. (2014) argued that organo-mineral interactions help explain SOM responses in Free-Air $\mathrm{CO}_{2}$ Enrichment (FACE) experiments and have global implications for future terrestrial carbon stocks. Recently, Ahrens et al. (2015) used a site-scale model (COMISSION) and observations from a site in Bavaria to demonstrate that SOC persistence is controlled by mineral surface stabilization and cyclic microbial assimilation and release. Our previous work with the BAMS1 model (Biotic and Abiotic Model of SOM; (Riley et al., 2014)) had similar conclusions. However, these models apply different approaches for sorption: Riley et al. (2014) applied separate adsorption and desorption rates to represent mineralprotected carbon, Sulman et al. (2014) described protected carbon with a first order turnover rate, and Ahrens et al. (2015) used a Langmuir sorption approach.

The level of model complexity required to accurately predict SOC dynamics under a changing climate remains unsettled (e.g., (Allison et al., 2010; Luo et al., 2015; Parton et al., 2010). Riley et al. (2014) showed that representing modest microbial diversity, organic chemistry, and a reasonable combination of sorption parameters led to good matches with observed soil organic carbon profiles without resorting to an arbitrary 
depth-dependent decline in SOM turnover rates, as is often done in existing SOM models. Upon this premise, exploring this modeling philosophy may lead to valuable characterization of vertically-resolved soil organic matter, transport, mineral surface interaction, and microbial ecological interactions. In this work, we applied BAMS1, which includes a microbially mediated SOM reaction network with two microbial functional groups (heterotrophic aerobic bacteria and fungi) and several polymer and monomer species. Dynamic adsorption and desorption with a surface complexation model were added to the model for this work.

The specific objectives of this study are to (1) explore and quantify how bulk mineral properties affect carbon stocks and residence times of soil organic matter and (2) identify dominant controls for carbon stocks and inventory. We used sensitivity analyses and comparisons with published data to investigate controls on soil carbon stocks and turnover across a seven-site marine-terrace grassland chronosequence in California (Masiello et al., 2004) and in a Chernozem steppe grassland site in Russia (Torn et al., 2002).

\section{Methodology and Model Inputs}

\subsection{Chronosequence Terrace Sites in Northern California}

This chronosequence comprises seven terraces on the northern California coast (between $38^{\circ}$ to $42^{\circ} \mathrm{N}$ and $122^{\circ}$ to $125^{\circ} \mathrm{W}$ ) that were formed on the same type of beach deposits but have soil development ages of 3.9, 29, 40, 118, 124, 124, and $240 \mathrm{ky}$, leading to significant differences in texture and mineralogical composition. We identify the Chronosequence Terrace (CT) sites as: CT-3.9ky, CT-29ky, CT-40ky, CT-118ky, 
CT-124ky-1, CT-124ky-2, and CT-240ky. Soil class ranges from mixed sandy soil (CT3.9ky) to coarse loamy (CT-29ky) to fine loamy (CT-40ky to CT-240ky) along the chronosequence. Clay content increases in CT sites with the age; for example, soils on CT-3.9ky and CT-29ky have 5\% and 15\% maximum clay content, respectively. Soils on CT-40ky, CT-118ky, CT-124ky-1, CT-124ky-2, and CT-240ky have at least 25-30\% maximum clay content (Merritts et al., 1991). Soils at the CT sites have been classified on the taxonomic soil order as Alfisols (Chadwick et al., 1990). The sites have a cool Mediterranean climate, with mean annual air temperature of $12{ }^{\circ} \mathrm{C}$ and mean annual precipitation of $1000 \mathrm{~mm}$ (Masiello et al., 2004; Merritts et al., 1991). These chronosequence terraces can be used to compare the effect of soil mineralogy and development while holding climate, vegetation, and other soil-forming factors relatively constant.

Merritts et al. (1991) described the soil development and mineralogy of these terraces in detail. The older sites are clay-rich and contain crystalline forms of iron-rich minerals. Total SOM content and SOM radiocarbon $\left(\Delta^{14} \mathrm{C}\right)$ were measured in one soil profile in each of the seven terraces (Masiello et al., 2004). Measured bulk SOM content is the lowest in the CT-3.9ky site, intermediate in the CT-29ky and CT-40ky sites, and highest in the older sites (CT-118ky, CT-124ky-1, CT-124ky-2, and CT-240ky) (Masiello et al., 2004). Because the older sites have experienced more weathering and have higher clay content as compared to younger sites, they present more mineral surface area available to sorb organic carbon (Mayer, 1994a). 


\subsection{Modern and 100-Year-Old-Soil Archives in Russian Steppe Sites}

The Russian steppe soils are classified as Mollisols on the taxonomic soil order and have relatively large carbon stocks. The soil on these sites are characterized as clay-loam and granular to sub-granular structure along the depth; clay content ranges from $24 \%$ to $30 \%$ in these sites ( Torn et al., 2002). Several studies have been conducted in this region to better understand soil carbon stocks and turnover (Guenet et al., 2013; Torn et al., 2002). We used data from the Kammenaya Steppe Preserve (51 $\left.02^{\prime} \mathrm{N}, 40^{\circ} 43^{\prime}\right)$. The vegetation was typical steppe prairie, dominated by herbaceous perennials with some woody perennials. The sampling sites have a mean annual temperature of $6.4{ }^{\circ} \mathrm{C}$ and mean annual precipitation of $520 \mathrm{~mm}$, with approximately $25 \%$ as snow. The snow cover typically lasts for slightly more than three months. SOM content and $\Delta{ }^{14} \mathrm{C}$ values were measured in three soil profiles (Archive, Pit1, and Pit2 soils) at this site. SOM content decreases from about $8 \%$ near the surface to less than $1 \%$ at $1.5 \mathrm{~m}$ depth.

\subsection{Carbon Decomposition Reaction Network}

To investigate how organo-mineral interactions influence SOM storage and dynamics, we modified the BAMS1 model (Riley et al., 2014) by incorporating a surface complexation model and reducing the complexity of monomer speciation (Fig. 1; Table 1). The modified BAMS1 includes a mechanistic representation of sorption processes. The reaction network consisted of (1) three groups of organic polymers (i.e., cellulose, hemicellulose, and lignin); (2) one representative simple organic monomer (or dissolved organic carbon (DOC)); (3) fungal and bacterial biomass; and (4) Dead Cell Wall Material (DCWM). However, we have not considered differences in chemical composition of DCWM between fungi and bacteria at this point, but we acknowledge the 
potential importance of such a distinction. Above and belowground litter and root exudates are partitioned between polymers and monomers and represent the carbon inputs to the system (Table 1). The decomposition of 1 mole of organic monomer yields $Y$ (g wet-biomass $\mathrm{mol}^{-1}$ ) microbial biomass. The fraction of carbon present in the substrate that is assimilated by microbes is defined as the assimilation-to-respiration ratio (e) (Table 1). The fraction (1-e) of organic monomers is respired as $\mathrm{CO}_{2}$ (Riley et al., 2014).

BAMS1 includes fungi and aerobic bacteria functional groups. Although substantially underrepresenting functional diversity in soils, this approach is practical given limits on observations for more detailed parameterization while maintaining the governing ecological functions in the ecosystem (Goldfarb et al., 2011). These microbial groups are assigned affinities to decompose plant litter and SOM (DeAngelis et al., 2013; Neely et al., 1991; Romaní et al., 2006; Thevenot et al., 2010) and on death produce dissolved organic monomer and DCWM (Frostegard and Bååth, 1996).

The model assumes that aerobic heterotrophic bacteria $\left(B_{A}\right)$ use organic monomers as a source of carbon for biomass growth and maintenance, leading to biomass yield and $\mathrm{CO}_{2}$ production (Fig. 1). Fungi are assumed to excrete exoenzymes, in proportion to their biomass, that depolymerize polymers into monomers for assimilation (Ahrens et al., 2015; Sulman et al., 2014). Transporter enzyme levels are also assumed proportional to biomass, leading to Michaelis-Menten-Monod growth kinetics, as described in Section 2.4.

A set of aqueous primary (e.g., monomers, cellulose) and secondary (aqueous and surface complexes and gaseous) species were defined that participated in the 
biogeochemical reaction network (Reed, 1982; Steefel and Lasaga, 1994; Yeh and Tripathi, 1991). The relationship between primary and secondary species is expressed as:

$P_{i}=\sum_{j=1}^{N_{c}} v_{i j} P_{j} \quad i=1, \ldots, N_{R}$

where $P$ represents chemical species, $N_{C}$ is the number of primary species, $j$ is the primary species index, $i$ is the secondary species index, $N_{R}$ is the number of reactions (one per each secondary species), and $v_{i j}$ is the stoichiometric coefficient of the $j^{\text {th }}$ primary species in the $i^{\text {th }}$ reaction.

\subsection{Biological Reaction Rates}

The microbial decomposition rate of substrate $C_{i}$ is calculated using MichaelisMenten kinetics (e.g., German et al., 2012; Riley et al., 2014). We note that MichaelisMenten kinetics may be an inappropriate representation in complex substrate-consumer networks (Tang and Riley, 2013); this potential complication is discussed in Section 4.4. Kinetic reactions among primary species, which include aqueous and sorption reaction kinetics and biodegradation, were represented using a general rate law:

$r_{i}=\sum_{s=1}^{M}\left[k_{i, s} \times \prod_{j=1}^{N_{i}}\left(\gamma_{j}^{v_{i, j}} C_{j}^{v_{i}, j}\right) \times \prod_{k=1}^{N_{m}}\left(\frac{C_{i, k}}{K_{M_{i}, k}+C_{i, k}}\right)\right]$

where $r_{i}$ is the reaction rate of the $i^{\text {th }}$ reaction with the number of mechanisms or pathways ranging from $s=1$ to $M ; k, \gamma_{\mathrm{j}}$, and $C_{j}$ denote the rate constant, activity coefficient, and concentration of species $j$, respectively; and $v_{i, j}, N_{i,} N_{m}, C_{i, k}$ represent the stoichiometric coefficient, number of reacting species in the forward rate term (product terms), number of Monod factors (Michaelis-Menten terms), and the concentration (mol $\left.\mathrm{L}^{-1}\right)$ of the $k^{\text {th }}$ Monod species, respectively. The first $\left[k_{i, s}\right]$, second $\left[\prod_{j=1}^{N_{i}}\left(\gamma_{j}^{v_{i, j}} C_{j}^{v_{i}, j}\right)\right]$, and third $\left[\prod_{k=1}^{N_{m}}\left(\frac{C_{i, k}}{K_{M_{i}, k}+C_{i, k}}\right)\right]$ terms on the right-hand side of Equation 2 are referred to as the 
rate constants, product terms, and Michaelis-Menten terms, respectively (e.g., Curtis, 2003).

\subsection{Surface complexation modeling}

Adsorption and desorption of SOC depend on characteristics of the organic molecules, soil mineral surfaces, and aqueous chemistry (Dudal and Gérard, 2004; Goldberg et al., 2007). There are various approaches for representing sorption processes, including kinetic and equilibrium adsorption isotherms (e.g., linear, Langmuir, Freundlich; (Davis and Kent, 1990)), and thermodynamic surface complexation models (e.g., Diffuse Layer Model) (Hiemstra et al., 1989; Sahai and Sverjensky, 1997a, 1997b). Several studies have found that DOC sorption onto mineral surfaces can be described by a Langmuir isotherm (Gu et al., 1994; Kothawala et al., 2008; Mayes et al., 2012). However, sorption models are parameterized only for the specific conditions for which they were derived, hence, they cannot account for out-of-sample (i.e., outside the parameterization data set) effects of chemical conditions on adsorption, desorption, and competitive sorption processes (e.g., Goldberg et al., 2007). In contrast, Surface Complexation Models (SCMs) consider variable biogeochemical conditions within a thermodynamic framework, by using mass action laws analogous to aqueous phase reactions. Since SCMs can account for changes in chemical speciation, competitive adsorption, and other multi-solute interactive chemical effects (Davis and Kent, 1990; Davis and Coston, 1998), we implemented an SCM in BAMS1 for this study.

The sorption of solutes on solid surfaces can be described as a chemical reaction between aqueous species and surface sites (surface complexation) (Dzombak, 1990).

$A+S \leftrightarrow A-S$ 
where $A$ is the sorbate molecule, $S$ is the sorbent site (surface); and $A-S$ represents the sorbed complex. At equilibrium, the sorption reactions can be described by a mass action law equation:

$K_{E q}=\frac{[A-S]}{[A][S]}$

where $K_{E q}$ is the equilibrium sorption constant, $[A-S]$ represents the concentration of surface complexes ( $\mathrm{mol} \mathrm{kg}^{-1}$ water), [A] is the concentration of sorbate molecule (mol kg${ }_{\text {water }}$ ), and $[\mathrm{S}]$ is the concentration of sorbent sites $\left(\mathrm{mol}_{\text {sites }} \mathrm{kg}^{-1}\right.$ water $)$. In this study, we investigated organo-mineral interactions in terms of the soil bulk specific surface area (SBSSA, $\mathrm{m}^{2} \mathrm{~g}_{\text {soil }}{ }^{-1}$ ) and equilibrium constraints. The concentration of sorbent sites is calculated from input SBSSA and site density $\left(\mathrm{mol}_{\text {sites }} \mathrm{m}^{-2}\right)$, from which $[\mathrm{S}]$ is then computed as a function of porosity and liquid saturation.

In the model, the total amount of available sorption sites $\left(\mathrm{mol}_{\text {sites }} \mathrm{g}_{\text {soil }}{ }^{-1}\right)$ limits the soil's capacity to store carbon and is calculated as the product of the SBSSA and site density. We assumed the soil with a bulk generic mineral surface with a site density of $7.68 \times 10^{-7} \mathrm{~mol}_{\text {sites }} \mathrm{m}^{-2}$, which represents a typical site density for clays and iron hydroxides (Davis and Coston, 1998) multiplied by an assumed weight fraction (taken as the clay content for each site) of such sorbing minerals in the soil. We assumed weight fractions for CT-3.9ky and CT-29ky as 0.05 and 0.15, respectively; for other sites (CT40ky to CT-240ky and Russian sites), we assumed a weight fraction of 0.3.

Monomers and DCWM are two primary species in the model that exist in the aqueous phase and undergo sorption. However, dissolved monomers and DCWM sorb onto bulk soil minerals differently (Riley et al., 2014). Therefore, BAMS1 represents monomers and DCWM sorption separately, but the sorption characteristics of individual 
minerals were not modeled. Instead, sorption onto soil minerals was modeled using an SBSSA without considering electrostatic interactions. Wattel-Koekkoek and Buurman, (2004) showed that the mean residence time of SOM is related to the cation-exchange capacity and specific minerals (e.g., kaolinite-bound organic matter), and electrostatic interactions may be important in modeling $\Delta{ }^{14} \mathrm{C}$ values of SOM. However, several studies suggest that it is not possible to quantify the charge correctly for assemblages of mixed minerals (e.g., soils and sediments) (Davis and Coston, 1998; Westall et al., 1995). Moreover, because of the heterogeneity of soil organic carbon molecules, it is reasonable to model SOM using a non-electrostatic approach (Westall et al., 1995). Detailed inclusion of mineral double-layer properties and spatially heterogeneous surface areas were deemed beyond the scope of this study, and beyond the level of first-order effects expected in our simulations. The SCM in this study was applied to simulations held at constant temperature and $\mathrm{pH}$, but it could be used to investigate impacts of temperature and $\mathrm{pH}$ based on data availability.

The decadic logarithm of the equilibrium sorption coefficients $\left(\log \left(K_{E q}\right)\right)$ of reactions of different functional groups of organic carbon with iron minerals has a wide range (8.25 to 13; (Lenhart and Honeyman, 1999; Murphy et al., 1999)). We assumed relatively smaller (9.08) and larger (11.25) $\log \left(K_{E q}\right)$ values for monomers and DCWM, respectively, based on our original work in BAMS1 (Riley et al. 2014). We show below with a sensitivity analysis (Sections 3.3 and 4.2) that $\log \left(K_{E q}\right)$ does not substantially affect equilibrium SOM values.

Several studies have reported that SBSSA increases with soil formation and age (up to a point) and decreases with increasing soil depth (Hodson et al., 1998; White et al., 
1996, 2009). However, variation of SBSSA with depth and time is complex. Consistent with the idea that SBSSA increases as soils age, Merritts et al. (1991) reported an increase in accumulated mass of several forms of pedogenic iron and clay across the Chronosequence Terrace sites. Although texture and mineralogical composition have been used to develop various SBSSA pedotransfer functions (Colin and Reid, 2013; Feller et al., 1992; Mayer, 1994b; White et al., 1996), it is difficult to accurately extrapolate SBSSA to other soils (Colin and Reid, 2013). Therefore, for simplicity, we consider SBSSA to be a generic bulk mineral surface area and calibrate its value at each of the ten sites, as described below. We then analyze relationships between SBSSA and observed clay content across the sites.

Vanwalleghem et al. (2013) showed that the rate of soil formation may be described using an exponentially decreasing function with depth, since many physical factors that control weathering, such as temperature and soil moisture, are known to have exponentially decreasing depth profiles (Amenu et al., 2005). On this basis, we assumed that each CT and Russian site exhibits an exponentially decreasing SBSSA with depth (a), i.e., $a=a_{0} e^{-z / z_{m}}$; where $\mathrm{z}$ is depth $(\mathrm{m}), z_{m}$ is a constant $(\mathrm{m})$, and $a_{0}$ is the nearsurface SBSSA. Because we did not have direct measurements of either $a_{0}$ or $z_{m}$, we estimated these parameters using SOM profiles observed at each site.

During estimation, for each value of $a_{0}$, we allowed $z_{m}$ to range from 0 to $6 \mathrm{~m}$ $(0.0,0.25,0.5,0.75,1,1.25,2,3,4,5,6) . z_{m}$ values of 0.0 and $6 \mathrm{~m}$ imply no gradient and the steepest gradient, respectively. The best-fit values for $a_{0}$ and $z_{m}$ were chosen for each site based on $\mathrm{R}^{2}$ values (or coefficient of determination) and root mean squared error 
(RMSE) between simulated and observed SOM content. $\mathrm{R}^{2}$ values are computed as follows:

$R^{2}=1-\frac{\left(O_{i-} M_{i}\right)^{2}}{\sum_{i=1}^{n}\left(O_{i-} \bar{O}\right)^{2}}$

where $O$ are the $n$ observed SOM values; $\bar{O}$ is the mean of the observed SOM values; and $M$ are the $n$ estimated $\mathrm{SOM}$ values by the model. $\mathrm{R}^{2}$ values range from 0 to $1 ; \mathrm{R}^{2}$ value 1 denotes the perfect match between modeled and observed values.

RMSE values are computed as follows:

$R M S E=\frac{\sum_{i=1}^{n}\left(O_{i}-M_{i}\right)^{2}}{n}$

RMSE values range from 0 to $\infty ; \mathrm{RMSE}=0$ denotes the perfect match between modeled and observed values.

We selected all values of $a_{0}$ and $z_{m}$ for each site when $\mathrm{R}^{2}$ and RMSE values were in the $80^{\text {th }}$ (top $20 \%$ ) and $50^{\text {th }}$ (top $50 \%$ ) percentiles. High $\mathrm{R}^{2}$ values ensure that predicted SOM values follow the qualitative SOM profile, and small RMSE values ensure that predicted SOM values are close to observations.

Estimated SBSSA $\left(a_{0}\right)$ values ranged from 6.8 to $17.4 \mathrm{~m}^{2} \mathrm{~g}_{\text {soil }}{ }^{-1}$ for the CT sites. For the Russian sites, the estimated SBSSA was $39.1 \mathrm{~m}^{2} \mathrm{~g}_{\text {soil }}{ }^{-1}$. The CT values were consistent with SBSSA values reported for soils elsewhere in California under similar climatic conditions (White et al., 1996). Subsequently, we used these values for $a_{0}$ and $z_{m}$ in BAMS1 to predict $\Delta^{14} \mathrm{C}$ values for each site that were estimated using SOM values.

\subsection{Reactive Transport Solver}

We integrated the modified reaction network (BAMS1) and surface complexation model in the one-dimensional version of the multi-phase flow and reactive transport 
simulator TOUGHREACT V2 (Xu et al., 2011). TOUGHREACT includes various processes to simulate flow and reactive transport in variably saturated, non-isothermal porous media, including advection; diffusion; representation of multiple competing microbial populations (Xu, 2008); adsorption and desorption; the soil energy budget; and equilibrium and kinetic chemical and biochemical reactions. The flow and transport are solved using integral finite difference spatial discretization. In addition, a sequential iteration approach as described in Yeh and Tripathi (1991) is used to solve chemical transport simulation. After solution of the flow equations, the fluid velocities and phase saturations are used for chemical transport simulation (Xu et al. (2011b). The DarcyRichards equation (Pruess, 1999) was used to model water flow, and the van Genuchten (1980) model was used to relate matric potential and hydraulic conductivity with soil water saturation. The overall mass balance equation was then solved in a onedimensional (1D) vertical domain:

$$
\frac{\partial C_{i}}{\partial t}=-\frac{\partial}{\partial z}\left[D \frac{\partial C_{i}}{\partial z}+v C_{i}\right]+\left.\sum_{k} \frac{\partial C_{i}}{\partial t}\right|_{k}
$$

where $\mathrm{z}(\mathrm{m})$ is the vertical dimension, $t(\mathrm{~s})$ is the time, $D\left(\mathrm{~m}^{2} \mathrm{~s}^{-1}\right)$ is the effective aqueous or gaseous diffusivity, and $v\left(\mathrm{~m} \mathrm{~s}^{-1}\right)$ is the bulk aqueous or gaseous velocity. The last term denotes the sum of sinks or sources resulting from $k$ reactive mechanisms.

\subsection{Representing $\Delta^{14} \mathrm{C}$ values of SOM}

SOM $\Delta{ }^{14} \mathrm{C}$ data are useful benchmarks of soil biogeochemical models, because $\Delta{ }^{14} \mathrm{C}$ values are a function of the residence time of soil carbon since its photosynthetic assimilation from the atmosphere (Torn et al., 2009; Trumbore, 2000). Based on $\Delta{ }^{14} \mathrm{C}$ observations, the residence time of SOM typically increases with depth (Jenkinson and Coleman, 2008; Torn et al., 1997a, 2002, Trumbore, 2000, 2009). We predicted SOM 
$\Delta{ }^{14} \mathrm{C}$ values by duplicating the reaction network into one set of reactions in terms of ${ }^{12} \mathrm{C}$ species, and a separate but identical set of reactions in terms of ${ }^{14} \mathrm{C}$ species neglecting combinatorial effects in molecules with multiple $\mathrm{C}$ atoms (see GEBIK and GEBIF equations in Maggi and Riley (2010)). We then applied a first order decay term $\lambda\left(\mathrm{s}^{-1}\right)$ for ${ }^{14} \mathrm{C}$ radioactive decay $(\lambda=1 / 8267 \mathrm{y})$ to all ${ }^{14} \mathrm{C}$ species in aqueous and sorbed phases. Predicted and observed $\Delta{ }^{14} \mathrm{C}$ values are reported in permil (\%) denoting parts per thousand (Stuiver and Polach, 1999).

To account for the ${ }^{14} \mathrm{C}$ bomb pulse, we imposed northern hemispheric $\Delta{ }^{14} \mathrm{C}$ values for 1950-1976 and 1977-2003 as reported by Levin and Hesshaimer (2000) and Levin and Kromer (2004), respectively, for the Northern California and Russian observations that were made in 2004 and 1997, respectively; the archived Russian soil was collected between 1895 and 1903, before ${ }^{14} \mathrm{C}$ release from nuclear weapons tests.

The observed $\Delta{ }^{14} \mathrm{C}$ values of $\mathrm{CT}$ soils decreased from about $0 \%$ to $-710 \%$. $\Delta{ }^{14} \mathrm{C}$ values are often more depleted in the older soils (CT-118ky, CT-124ky-1, CT-124ky-2, and CT-240ky) than the younger soils at the same depth; however, there are slightly higher $\Delta{ }^{14} \mathrm{C}$ values in CT-240ky than in CT-118ky (Masiello et al., 2004). The Russian soils have $\Delta^{14} \mathrm{C}$ data from the pre-bomb era (Torn et al., 2002). These soils were sampled 100 years apart; the $\Delta^{14} \mathrm{C}$ values decreased from about $0 \%$ to $-700 \%$, indicating very old carbon at depth.

\subsection{Climate Forcing, Boundary Conditions, and Initial Conditions}

For terraces in California, mean precipitation and evapotranspiration were imposed as $1000 \mathrm{~mm} \mathrm{yr}^{-1}$ and $300 \mathrm{~mm} \mathrm{yr}^{-1}$, respectively (Masiello et al., 2004; http://www.ntsg.umt.edu/project/mod16). For Russian sites, mean precipitation and 
evapotranspiration were imposed as $520 \mathrm{~mm} \mathrm{yr}^{-1}$ and $460 \mathrm{~mm} \mathrm{yr}^{-1}$, respectively (Frolov, 2014; Torn et al., 2002).

Root profiles for the chronosequence terrace and Central Chernozem Region grasslands were selected from the Global Root Distribution Profile database (Schenk and Jackson, 2002, 2005) (available in ESA's Electronic Data Archive: Ecological Archives M072-004-A1: http://www.esapubs.org/archive/mono/M072/004/appendix-A.htm).

We imposed carbon inputs from leaf, wood, and root litter based on simulations using CLM4.0 (Lawrence et al., 2011) and partitioned into the soil using separate exponentially depth-distributed profiles. Baseline simulations with no soil carbon as an initial condition and constant climate forcing were run for 5,000 years, except for the youngest site, which was run for 3,900 years, corresponding to its estimated age. We verified that 5,000 years of simulations produced ${ }^{12} \mathrm{C}$ and ${ }^{14} \mathrm{C}$ values for all components that were within $0.1 \%$ of those after 10,000 years of simulations. Therefore, 5,000 years of simulations were effectively at steady state; the 5000-year simulations were subsequently performed for computational tractability.

\subsection{Model Analyses}

We simulated carbon cycling of the Chronosequence Terrace sites with unchanged vegetation, temperature, and precipitation conditions, but varying the SBSSA (Table 2). We performed analogous simulations for soils of the Central Chernozem Region of Russia. We performed sensitivity analyses of SOM and $\Delta{ }^{14} \mathrm{C}$ profiles to changes in SBSSA, sorption coefficients, and vertical carbon input profiles using the CT$29 \mathrm{ky}$ site. Model predictions were compared to observations using $\mathrm{R}^{2}$ and RMSE values as described by Equations 5 and 6 . 


\section{Results}

\subsection{SOM Predictions for the Chronosequence Terrace and Chernozem sites}

We performed simulations to estimate total SOM stocks for the Chronosequence Terrace sites, where mineral composition varied significantly with site age along the chronosequence (Merritts et al., 1991). To determine whether observed patterns in carbon stock among the sites could be caused by changes in mineralogy, we imposed the SBSSA given in Table 2. For site CT-3.9ky, there was only one combination that met the $\mathrm{R}^{2}$ and RMSE criteria. For site CT-29ky, there were three combinations of the SBSSA $\left(\mathrm{m}^{2} \mathrm{~g}_{\text {soil }}{ }^{-1}\right)$ [(a) 9.3, (b) 11.6, and (c) 13.9] and the corresponding exponential decreasing constants [(a) 0, (b) 0.5, and (c) 0.5], but two of the best three RMSE values (a and c) were more than $30 \%$ and $50 \%$ greater than the smallest RMSE value. Additionally, three combinations had little difference in $\mathrm{R}^{2}$ values [(a) 0.768 (b) 0.768 (c) 0.761 for site CT$29 \mathrm{ky}]$. For all other sites, we chose the range of $a_{0}$ and $z_{m}$ based on the smallest RMSE values. We also report the range of $a_{0}$ and $z_{m}$ that had RMSE values within $10 \%$ of the smallest RMSE value for each site (Table 2). We found that $a_{0}$ and $z_{m}$ have increasing trends along the chronosequnce. The increasing trend of $a_{0}$ along the chronosequence is consistent with the idea that older sites experience more weathering and therefore have higher SBSSA. The larger $z_{m}$ for older sites is consistent with weathering occurring over a longer time extent.

The model predictions with the best-fit parameters broadly matched the observed total and vertical SOM profiles in these sites (Fig. 2). Total SOM (between 0 and $2 \mathrm{~m}$ depth) was accurately predicted across these seven Chronosequence Terrace sites $\left(R^{2}=\right.$ 0.81). Good matches with observed SOM profiles were predicted in the three youngest 
sites (CT-3.9ky, $\mathrm{R}^{2}=0.75$; CT-29ky, $\mathrm{R}^{2}=0.76$, and CT-40ky, $\left.\mathrm{R}^{2}=0.94\right)$. Although we report $\mathrm{R}^{2}$ values for the comparison between predicted and observed SOM values across depth, we note that this statistic should be interpreted carefully, since there are strong correlations across depth of SOM stocks. For example, a model error near the surface can propagate to depth, where it may result in larger error, but that error will not be indicative of model process representation errors at that depth. The least weathered site (CT-3.9ky) had the least SOM in both observations and predictions. For the older sites (CT-118ky, CT-124ky-1, CT-124ky-2, and CT-240ky), the model relatively accurately predicted SOM above $0.50-1.0 \mathrm{~m}$ depth and over-predicted SOM below $1.0 \mathrm{~m}$ depth. We discuss these discrepancies in Section 4.1.

We performed analogous simulations to estimate total SOM stocks at the three Chernozem sites (one archive and two modern soils) and compared the results to observations by Torn et al. (2002). Simulation results for all three sites had good overall correlations with observations $\left(\mathrm{R}^{2}=0.97,0.96\right.$, and 0.90 for the Archive, Pit1, and Pit2 soils, respectively; Fig. 3). However, the model slightly under-predicted SOM content between 0.2 and $0.5 \mathrm{~m}$ and over-predicted SOM content below $0.7 \mathrm{~m}$ for the Archive soils. The variation in the field observations gives an indication of the spatial heterogeneity and sampling and analytical precision, since the three observational datasets are nearby in the same system.

Although we do not have observations of individual SOM components to compare to our predictions, the predicted vertical profiles highlight the processes predicted to control bulk SOM content. For example, at the CT-29ky site (Fig. 2B), input polymers (lignin, cellulose, hemicellulose) were predicted to be in the top meter of soil at 
steady state, due to imposed vertical carbon input profiles and model assumption that polymers are not transported by advection (Figs. 4D, 4E, 4G). Lignin had the largest concentration among input polymers.

Because monomers can dissolve into the aqueous phase and move vertically by advection and diffusion, sorbed monomers had a deeper concentration profile (Figs. $4 \mathrm{H}$, 4I) than did the input polymers (Figs. 4D, 4E, 4G). Predicted aerobic bacteria (Fig. 4A) comprised more than $90 \%$ of the total microbial biomass, while the fungal biomass (Fig. 4B) was largest at the surface and declined rapidly with depth.

\section{2 $\quad \Delta{ }^{14} \mathrm{C}$ predictions of total SOM}

Simulations at the Chronosequence Terrace sites (Fig. 5) resulted in $\Delta^{14} \mathrm{C}$ values with profiles qualitatively consistent with observations. The model under-predicted $\Delta^{14} \mathrm{C}$ values in the top $0.2 \mathrm{~m}$ of the three younger sites (CT-3.9ky, CT-29ky, CT-40ky), but predictions were close $(10 \%$ - 40\%o) to observations between $0.20 \mathrm{~m}$ and $1 \mathrm{~m}$ depth in the CT-29ky and CT-40ky sites, respectively. Observed $\Delta^{14} \mathrm{C}$ values in the CT-3.9ky site did not follow a clear pattern with depth, and the model did not predict this high variability. In the older sites (CT-124ky-1, CT-124ky-2, CT-118ky, CT-240ky), predictions deeper than $0.2 \mathrm{~m}$ were consistently less ${ }^{14} \mathrm{C}$ depleted or younger than the observations. We performed sensitivity studies (perturbing SBSSA, sorption coefficients, and carbon input profiles) to identify mechanisms potentially responsible for biases between the model predictions and observations.

At the Chernozem site, the model predictions qualitatively matched the $\Delta^{14} \mathrm{C}$ value profile down to $1 \mathrm{~m}$ in the Archive and Pit2 soils, and accurately matched the two available data points in the shallow soil (at $0.2 \mathrm{~m}$ depth) in the Pit1 soil (Fig. 6). In the 
Archive and Pit1 soils, the predicted $\Delta{ }^{14} \mathrm{C}$ values were less depleted than observed below $1 \mathrm{~m}$ depth, while the deeper Pit2 soil $\Delta{ }^{14} \mathrm{C}$ observations were more accurately captured. Also, the model (1) over-estimated ${ }^{14} \mathrm{C}$ depletion in the top $0.1 \mathrm{~m}$ in both the Archive and Pit1/Pit2 observations; (2) predicted a larger incorporation of the bomb ${ }^{14} \mathrm{C}$ signal between about 0.2 and $1 \mathrm{~m}$ than observed; and (3) about correctly captured the observed differences in the top $0.1 \mathrm{~m} \Delta{ }^{14} \mathrm{C}$ values between the Archive and post-bomb Pits.

Although observations of $\Delta{ }^{14} \mathrm{C}$ values for individual SOM components were not available for comparison with our predictions, vertical $\Delta{ }^{14} \mathrm{C}$ profiles for individual SOM components may indicate the processes predicted to control bulk SOM content and $\Delta^{14} \mathrm{C}$ values. For example, using simulations from the CT-29ky site (Fig. 5B), the microbial biomass (aerobic bacteria) and dissolved monomers $\Delta^{14} \mathrm{C}$ values (Fig. 7) broadly follow the bulk SOM $\Delta{ }^{14} \mathrm{C}$ values (Fig. 5B), indicating rapid recycling of SOM between sorbed and dissolved phases, and the relatively fast turnover by aerobic bacteria. The more depleted $\Delta^{14} \mathrm{C}$ values of fungal biomass below the $\mathrm{C}$ input zone (below about $0.7 \mathrm{~m}$ )

occurred because of fungal decomposition of DCWM. The predicted $\Delta^{14} \mathrm{C}$ values for DCWM, which was used in the model to represent microbial cell wall polymers resulting from microbial death, were relatively depleted even in the top $0.5 \mathrm{~m}$ of soil. The fraction of sorbed SOM that is DCWM increased monotonically with depth below $1 \mathrm{~m}$ (not shown), reaching $15 \%$ by $2 \mathrm{~m}$ depth from $8 \%$ at $1 \mathrm{~m}$ depth.

\subsection{Sensitivity Analysis for Total SOM}

To better characterize the impact of organo-mineral interactions on SOM dynamics, we analyzed the sensitivity of SOM content to SBSSA, sorption coefficients, 
and carbon input profiles. For these analyses, CT-29ky site was used as the baseline scenario (Fig. 2B).

We varied SBSSA by $\pm 10 \%, \pm 20 \%$, and $\pm 50 \%$ from the baseline value for this site throughout the soil column. Resulting variations in SOM stocks were approximately proportional to these changes (Fig. 8A). Varying monomer and DCWM sorption coefficients $\left(K_{E q}\right)$ throughout the soil column by $\pm 10 \%, \pm 20 \%$, and $\pm 50 \%$ from the baseline value had little impact on SOM stocks (Figs. 8B and 8C).

In order to test the sensitivity of the depth distribution of plant inputs on vertically-resolved SOM stocks, we varied $z_{m}$ by $\pm 10 \%, \pm 20 \%$, and $\pm 50 \%$ from the baseline values but held the total rate of carbon inputs unchanged. These carbon input profiles changes had little impact on SOM stocks in the soil column (Fig. 8D), primarily because more than $90 \%$ of available sorption sites were occupied (Fig. 9) by sorbed monomers and DCWM (Figs. 4 and 9). The differences in carbon saturation associated with the different carbon input profiles were less than $5 \%$ in the top meter. Below $1 \mathrm{~m}$, the differences in carbon saturation were within $\pm 15 \%$ of the baseline simulation. However, the SOM content was less than $0.0001 \mathrm{~kg}_{\mathrm{C} \mathrm{kg}}{ }^{-1}$ soil below $1 \mathrm{~m}$ depth.

\subsection{Sensitivity Analysis for SOM $\Delta{ }^{14} \mathrm{C}$ Values}

We conducted a sensitivity analysis of $\Delta^{14} \mathrm{C}$ values with the same variations described for SOM stocks. Altering SBSSA and sorption coefficients throughout the column by $\pm 10 \%, \pm 20 \%$, and $\pm 50 \%$ from the baseline values (CT-29ky) had very small effects on $\Delta^{14} \mathrm{C}$ (Figs. 10A, 10B, and 10C). In contrast, changes in the vertical carbon input profiles had large impacts on $\Delta^{14} \mathrm{C}$ (Fig. 10D), with the shallower carbon input profiles producing more depleted $\Delta^{14} \mathrm{C}$ values below about $0.2 \mathrm{~m}$ depth. Enhanced 
depletion occurred because SOC in deeper soil was not replenished by new carbon as quickly in the case of shallower carbon input profiles because of retardation caused by transport, microbial consumption and release through mortality, and sorption. Moreover, even though bulk SOM stock was not sensitive to carbon input profile due to saturation of soil bulk specific surface area, the deeper carbon input profiles introduced new carbon deeper into the soil, resulting in less depleted $\Delta{ }^{14} \mathrm{C}$ values in the deeper carbon input profile scenario relative to the shallow carbon input scenario.

\section{Discussion}

\subsection{Predicted SOM Stocks and $\Delta^{14} \mathrm{C}$ Values}

The modified BAMS1 model predicted SOM stocks for the seven Chronosequence Terrace sites in broad agreement with observed profiles $\left(\mathrm{R}^{2}\right.$ between 0.75 and 0.94$)$ and for the three Russian grassland profiles in excellent agreement $\left(\mathrm{R}^{2}\right.$ between 0.90 and 0.97 ) with observed profiles. We note that it is possible to relatively accurately calibrate different types of SOM decomposition models against integrated near-surface bulk SOM observations (He et al., 2014; Luo et al., 2015). However, it is difficult to infer the relative importance of various decomposition mechanisms by using bulk SOM observations alone.

For comparison, the recent study by Ahrens et al. (2015) used more extensive measurements (total and $\Delta{ }^{14} \mathrm{C}$ values of $\mathrm{SOC}$ and mineral-associated carbon and microbial biomass) at a single site to calibrate 11 parameters in their vertically-resolved SOM model. Sulman et al. (2014) used the responses of microbial biomass and decomposition of monomers to amendments of a simple substrate to calibrate microbial 
and decomposition parameters of their model. Our approach of calibrating only two parameters to predict total SOM, and then using SOM $\Delta^{14} \mathrm{C}$ values as independent tests for the calibration, is sufficiently robust to justify using the model to evaluate hypotheses relating mineral controls on SOC stabilization to SOM storage. However, we acknowledge that more measurements of system properties could improve model calibration, which we will pursue in future work. Specific examples of abiotic and biotic properties that would be valuable within a model structure like BAMS1 include e.g., mineral adsorbed SOM, chemical properties of dissolved monomers, microbial biomass and activity, and mineral surface properties (Conant et al., 2011).

The secondary constraint of accurately representing vertically-resolved SOM $\Delta^{14} \mathrm{C}$ values implies that BAMS1 is more likely accounting for the mechanisms important in establishing observed vertical profiles of soil organic matter. For instance, predictions of $\Delta^{14} \mathrm{C}$ values of modeled carbon components (Fig. 7) showed that the fungal $\Delta^{14} \mathrm{C}$ values were relatively enriched and close to atmospheric values, because fungi degrade input polymers (cellulose, hemicellulose, lignin), which was consistent with the relatively fast turnover of these compounds. In addition, the predicted $\Delta^{14} \mathrm{C}$ values for DCWM were comparatively depleted even near the surface. This depletion occurred because we assumed that the cell wall material is relatively difficult to decompose when sorbed to mineral surfaces, and therefore accumulated over long periods. Altogether, our model results indicate that (1) relatively fast microbial SOM cycling ( o(0.1 to $1 \mathrm{y})),(2)$ vertical transport, (3) mineral stabilization, and (4) relatively slow decomposition of DCWM led to predictions that were consistent with observed vertical profiles of SOM bulk content and $\Delta^{14} \mathrm{C}$ values. 
These mechanisms are consistent with conclusions from recent studies that emphasize the importance of interactions among substrate availability, microorganisms, mineral surfaces, and slow depolymerization of substrates like DCWM in determining SOM profiles (Dungait et al., 2012; Kögel-Knabner, 2002; Schmidt et al., 2011). The mechanisms represented in BAMS1 did not impose intrinsic long turnover times and are in contrast to the widely applied pseudo-first-order SOM decomposition models, which impose a range of intrinsic decomposition rates on modeled SOM pools (Braakhekke et al., 2011, 2014; Koven et al., 2013; Parton et al., 1987). For example, RothPC-1 (Jenkinson and Coleman, 2008) and CLM4.5 (Koven et al., 2013) impose depthdependent SOM decomposition rates, mimicking the reduced microbial activity at depth that is dynamically prognosed in BAMS1.

Although pseudo-first-order approaches (Braakhekke et al., 2011; Jenkinson and Coleman, 2008; Koven et al., 2013; Tang et al., 2013) have been calibrated to represent vertical gradients of SOM content, they will likely predict different perturbation responses (compared to BAMS1) to changes in temperature, moisture, $\mathrm{pH}$, and carbon inputs expected under climate change (Riley et al. 2014). Along the same line, Luo et al. (2015) highlighted that pseudo-first-order models of SOM lead to large uncertainty in predicting soil carbon and perturbation responses, particularly with future expected warming and drying conditions. They further emphasized the need to represent the microbial community and its carbon use efficiency as a function of environmental changes for accurate predictions of SOM stocks. For example, an earlier perturbation analysis with BAMS1 (Riley et al., 2014) showed that interactions between microbial activity and vertical transport can lead to rapid changes in decomposition rates (e.g., from 
microbial priming) that would not emerge in a pseudo-first-order model that does not explicitly represent microbial activity.

Schimel et al. (2011) observed that pulsed drying and wetting events led to respiration from relatively old SOM, indicating that this old SOM may not be inert because of its association with mineral surfaces. Xu et al. (2004) reported the occurrence of short-lived, but high-rate respiratory pulses after rain events in a California grassland site. Lawrence et al. (2009) found that accounting for explicit exoenzyme and microbial decomposition controls improved representation of pulsed rewetting responses, although the simpler pseudo-first-order models they applied were more accurate under steady-state conditions. Our, and the recent results described above, argue that explicitly representing microbial activity and organo-mineral interactions in land models may improve carbon cycle predictions under dynamic climate forcing conditions.

\subsection{Sensitivity Analyses}

Soil surface properties change during soil development due to the formation of clays and other sorbent minerals (e.g., amorphous or poorly crystalline aluminum, iron, and manganese hydroxides), which can store more SOM than ordered minerals associated with younger soils (Masiello et al., 2004; Mayer, 1994a; Merritts et al., 1991; Six et al., 2000). There is evidence that SBSSA increases with age up to a certain point, and then decreases (e.g., in Oxisols) (Hodson et al., 1998). Moreover, soil weathering affects SBSSA and reactivity (Maher et al., 2009; White et al., 1996, 2009). To examine these interactions within our modeling framework, we performed sensitivity analyses around our baseline values of soil bulk specific surface area and sorption coefficients. SOM content was affected throughout the column approximately proportionally to the imposed 
changes in SBSSA (Fig. 8A). Thus, a fractional change in SBSSA led to a comparable fractional change in SOM storage, at equilibrium. These results are consistent with previous studies that noted a positive correlation between mineral content and organic carbon in soils (Kaiser and Guggenberger, 2003; Mayer, 1994b).

In contrast, the imposed changes in monomer and DCWM sorption coefficients did not affect SOM stocks (Fig. 8B). If sorption sites are mostly saturated (as they are at equilibrium in our simulations), increasing the sorption coefficients does not change the amount of sorbed monomers or DCWM. In particular, changes in sorption coefficients at or near saturation of mineral surface sites had little impact on SOM content.

Several studies have suggested that weathering-related controls on SOM content are likely related to the surface chemistry of primary and secondary minerals (Chorover et al., 2004; Guggenberger and Kaiser, 2003). In our sensitivity analyses, we found that SOM $\Delta{ }^{14} \mathrm{C}$ values were largely unaffected by imposed changes in SBSSA and sorption coefficients (Figs 10A, 10B, 10C). This result is consistent with the model structure we imposed in BAMS1, where an increasing sorption capacity resulted in an increased adsorbed carbon pool in equilibrium with an aqueous concentration that is similar to that predicted with the original sorption capacity. The aqueous carbon concentration is effectively set by microbial activity, which is relatively constant as a function of sorption capacity. The microbial activity sets the effective decomposition rate of carbon inputs, thus leading to similar $\Delta{ }^{14} \mathrm{C}$ values and inferred turnover times. A recent study conducted by Ahrens et al. (2015) also concluded that microbial interactions and aqueous carbon concentration control $\Delta{ }^{14} \mathrm{C}$ at depth and that sorption acts a buffer for aqueous carbon concentration in the soil column. Sorption processes suppress microbial activity by 
physically protecting substrate and maintaining equilibrium microbial activity by gradually releasing carbon in the soil column as suggested in Riley et al. (2014).

The BAMS1 receptor-controlled decomposition rate is in contrast to the donorcontrolled decomposition mechanism imposed in multi-pool, pseudo-first-order carbon decomposition models. In those models, larger SOM content could be obtained by reducing the turnover times (e.g., of the 'slow' pool), and arguing that the turnover times were functions of soil mineral properties. The result of such a change would be longer residence times. Thus, BAMS1 prognoses different $\Delta^{14} \mathrm{C}$ patterns in response to differences in soil mineralogy relative to models that impose longer turnover times, creating and highlighting an observational metric to inform which type of model structure is more appropriate.

Leifeld et al. (2009) reported that the residence time inferred from $\Delta{ }^{14} \mathrm{C}$ measurements of mineral-associated organic matter was positively related to soil mineral surface area. In our simulations, SBSSA is strongly positively correlated with $\Delta^{14} \mathrm{C}$ values across depth at the CT sites (except for the youngest site; CT-3.9ky), and positively correlated at a lower level at CT-3.9ky, CT-29ky, CT-118ky, and CT-124ky for $\Delta^{14} \mathrm{C}$ integrated over depth. We also found low sensitivity of predicted $\Delta^{14} \mathrm{C}$ values to SBSSA in our sensitivity analysis of the CT-29ky site, as described above. We therefore conclude that the observed and modeled correlation between SBSSA and $\Delta^{14} \mathrm{C}$ values across depth is not causative, but rather emerges from the combination of microbial activity, vertical transport of monomers, and stabilization on mineral surfaces.

Changes in the vertical carbon input profiles had a negligible impact on the bulk SOM profiles, which is consistent with studies that have shown that mineral-associated 
SOM is a function of the carbon saturation deficit (Castellano et al., 2015; Cotrufo et al., 2013). In addition, Holub et al. (2005) found little impact of belowground organic carbon input profile on SOM stocks in two different forest soils after 4 and 11 years. Clearly, there is an upper limit to the equilibrium mineral soil carbon level associated with the soil carbon saturation capacity. Stewart et al. (2009) argued that carbon stabilization capacity can be quantified for different SOM pools, e.g., non-protected vs. physically, chemically, or biochemically protected SOM pools. A potential reason for a small effect of carbon input profiles on SOM content is that sorption sites were saturated at steady state (Fig. 9). Several observational studies have also demonstrated that mineral-associated fractions exhibit carbon-saturation behavior (Castellano et al., 2015; Hassink and Whitmore, 1997). Most contemporary SOM models assume a strong linkage between carbon input profiles (root, litter, and wood litter) and SOM accumulation, but soils have finite capacities to accumulate carbon (Gottschalk et al., 2012). Soils may become saturated and reach equilibrium because of different combinations of soil texture, mineralogy, and climatic regimes (Chung et al., 2010; Six et al., 2002; Stewart et al., 2009). Therefore, it is desirable to represent carbon-saturation behavior of soils in SOM models.

In contrast, vertical carbon input profiles had a significant impact on predicted SOM $\Delta{ }^{14} \mathrm{C}$ values (Fig. 10D). Sorbed monomers and DCWM dominated bulk SOM content below $0.7 \mathrm{~m}$. SOM $\Delta{ }^{14} \mathrm{C}$ values reflect the carbon residence time, which varies with carbon input profile; for example, deeper carbon input profiles will add younger carbon to deeper soil organic matter. Similarly, some studies of soil carbon storage and turnover demonstrated that, at a particular soil depth, carbon residence time is associated with input rates at that depth (Trumbore, 2009; Wang et al., 2013). Since we perturbed 
vertical carbon input profiles while keeping the total carbon input equal, we conclude that variations in carbon input depth profiles can alter SOM residence time because of microbial and abiotic controls on SOM cycling.

\subsection{SOM Modeling Approaches}

Currently, there are two broad classes of SOM models capable of integration with climate-scale land models: (1) pseudo-first order multi-pool models and (2) models representing explicit microbial and physical protection processes. Each of these model structures can be calibrated to match current SOM observations, but they will likely predict very different responses to climate perturbations. Clearly, there are trade-offs between model structural complexity, parameterization, and computational tractability in representing carbon dynamics at larger scales. Although current analyses are insufficient to argue that the increased complexity of the more mechanistic models will increase predictive capability under dynamic climate forcing, we argue that further development is warranted because these models integrate known relevant mechanisms (e.g., microbial dynamics, SOM chemical composition, and mineral-surface versus aqueous SOM partitioning) and are therefore expected to provide an explanation to observations of these mechanisms. One possible approach to reduce the additional computational costs associated with more complex SOM representations is the development of reduced order or surrogate models that could capture much of the important dynamics at substantially lower computational costs than the full model (e.g., (Pau et al., 2016)).

\subsection{Caveats and Future Model Development}

We modeled chemical components that were not observed individually to test our model. Although, it is possible to achieve total SOM content with various combinations 
of parameters, we used various metrics to test the validity of our assumptions, e.g., lignin content, fungi-to-aerobic bacteria biomass ratios, and $\Delta{ }^{14} \mathrm{C}$ values of SOM. We have not tested model structural uncertainty because of unavailability of observations of each modeled component; however, our analysis provides insights into processes that are not possible with a pseudo-first order SOM modeling framework.

As with all SOM modeling analyses, the complexity of SOM dynamics requires substantial simplification of process representation and interconnections between processes. Among the many potential resulting problems, an interesting complication in representing microbial SOM dynamics arises because of recent work suggesting that Michaelis-Menten kinetics (which we applied here and are commonly applied in most microbe-explicit SOM models) may be inappropriate to represent the complex consumer, substrate, and abiotic interactions that occur during SOM decomposition (Tang and Riley, 2014; Tang et al., 2013) as well as in combinatorial isotope speciation and fractionation (Maggi and Riley, 2010). We did not apply these concepts in the current analysis but acknowledge that uncertainties in these interactions may cause uncertainty in our model results.

We also did not account here for temporal frequency of climate forcing (Arora et al., 2016; Grant et al., 2006; Lawrence et al., 2009; Schimel et al., 2011), feedbacks with vegetation (Turner et al., 2004), and nutrient constraints on decomposition (Parton et al., 1987), despite their potential importance on emergent SOM profiles; future work will address these shortcomings.

The model introduced here represents a one-dimensional soil column, but terrestrial ecosystems have spatial horizontal heterogeneity that may affects SOM 
dynamics in non-uniform soil formations (Arora et al., 2011; Frei et al., 2012; Li et al., 2008; Molins et al., 2012). Moreover, pore and molecular-scale processes and their effects on carbon exchanges between land and the atmosphere are expected to vary because of the temporal variability associated with many factors, including climate (Koven et al., 2013), lithology (Jobbágy and Jackson, 2000), seasonal dynamics (Grant et al., 2006), interfacial chemistry (Torn et al., 1997b), edaphic properties (Bird et al., 2002), soil moisture (Riley and Shen, 2014; Sivapalan, 2005), temperature (Davidson and Janssens, 2006), and vegetation (Turner et al., 2004). To bridge gaps between molecular, site-, regional-, and climate-scale modeling, interdisciplinary and multi-scale approaches will be required to account for the complex feedbacks that occur between hydrology, plant processes, microbial degradation, and mineralogical controls on carbon stocks and residence time.

\section{Conclusions}

We modified BAMS1, by incorporating a surface complexation model and reducing the complexity of monomer speciation, and integrated it with a vertically-resolved, multiphase reactive transport solver (TOUGHREACT) to investigate the impact of soil mineralogy on SOM dynamics. By accounting for microbial activity, sorption, and vertical transport, the model reasonably predicted SOM stocks and $\Delta{ }^{14} \mathrm{C}$ values at seven sites along a soil chronosequence in Northern California and three grassland sites in Russia. Model predictions were consistent with expectations of fungi:aerobic bacteria ratios. Our sensitivity analyses indicated that SBSSA was the dominant control over organic carbon stocks at these sites and that sorption coefficients did not strongly affect 
total SOM stocks. We found that the observed and modeled correlation between SBSSA and $\Delta^{14} \mathrm{C}$ values across depth at each site is not causative, but rather emerges from the combination of microbial activity, vertical transport of monomers (DOC), and stabilization on mineral surfaces. Our model sensitivity analyses at an intermediate age site (CT-29ky) highlighted the impact of sorption coefficients and SBSSA on SOM $\Delta^{14} \mathrm{C}$ values (which is a proxy of SOM residence times). Predicted SOM $\Delta^{14} \mathrm{C}$ values showed little sensitivity to changes in sorption coefficients of monomers and dead cell wall material and to the SBSSA, but were very sensitive to vertical carbon input profiles. Our results demonstrate that a model structure with explicit microbial activity, individual SOM components, vertically-resolved aqueous transport, and mineral surface sorption can lead to realistic bulk SOM and $\Delta^{14} \mathrm{C}$ values, and that the emergent system responses to model parameters and inputs will be different than those from traditional pseudo-first order models. We therefore conclude that integration of this type of more mechanistically explicit model structure should be considered in climate-scale land models.

Acknowledgments: This research was supported by the Director, Office of Science, Office of Biological and Environmental Research of the US Department of Energy, under contract no. DE-AC02-05CH11231, as part of the Next-Generation Ecosystem Experiment (NGEE Arctic) project and the TES SFA. 


\section{References}

Ahrens, B., Braakhekke, M., Guggenberger, G., Schrumpf, M. and Reichstein, M.: Contribution of sorption, DOC transport and microbial interactions to the $14 \mathrm{C}$ age of a soil organic carbon profile: Insights from a calibrated process model, Soil Biol. Biochem., 88, 390-402, doi:10.1016/j.soilbio.2015.06.008, 2015.

Allison, S. D., Wallenstein, M. D. and Bradford, M. A.: Soil-carbon response to warming dependent on microbial physiology, Nat. Geosci., 3(5), 336-340, doi:10.1038/ngeo846, 2010.

Amenu, G. G., Kumar, P. and Liang, X.-Z.: Interannual Variability of Deep-Layer Hydrologic Memory and Mechanisms of Its Influence on Surface Energy Fluxes, J. Clim., 18(23), 5024-5045, doi:10.1175/JCLI3590.1, 2005.

Arora, B., Dwivedi, D., Hubbard, S. S., Steefel, C. I. and Williams, K. H.: Identifying geochemical hot moments and their controls on a contaminated river floodplain system using wavelet and entropy approaches, Environ. Model. Softw., 85, 27-41, doi:10.1016/j.envsoft.2016.08.005, 2016.

Arora, B., Mohanty, B. P. and McGuire, J. T.: Inverse estimation of parameters for multidomain flow models in soil columns with different macropore densities, Water Resour. Res., 47, doi:10.1029/2010WR009451, 2011.

Bird, S. B., Herrick, J. E., Wander, M. M. and Wright, S. F.: Spatial heterogeneity of aggregate stability and soil carbon in semi-arid rangeland, in Environmental Pollution, vol. 116, pp. 445-455., 2002.

Braakhekke, M. C., Beer, C., Hoosbeek, M. R., Reichstein, M., Kruijt, B., Schrumpf, M. and Kabat, P.: Somprof: A vertically explicit soil organic matter model, Ecol. Modell., 222, 1712-1730, doi:10.1016/j.ecolmodel.2011.02.015, 2011.

Braakhekke, M. C., Beer, C., Schrumpf, M., Ekici, A., Ahrens, B., Hoosbeek, M. R., Kruijt, B., Kabat, P. and Reichstein, M.: The use of radiocarbon to constrain current and future soil organic matter turnover and transport in a temperate forest, J. Geophys. Res. Biogeosciences, 119, 372-391, doi:10.1002/2013JG002420, 2014.

Castellano, M. J., Mueller, K. E., Olk, D. C., Sawyer, J. E. and Six, J.: Integrating Plant Litter Quality, Soil Organic Matter Stabilization and the Carbon Saturation Concept., Glob. Chang. Biol., doi:10.1111/gcb.12982, 2015.

Chadwick, O. A., Brimhall, G. H. and Hendricks, D. M.: From a black to a gray box - a mass balance interpretation of pedogenesis, Geomorphology, 3(3-4), 369-390, doi:10.1016/0169-555X(90)90012-F, 1990.

Chorover, J., Amistadi, M. K. and Chadwick, O. A.: Surface charge evolution of mineralorganic complexes during pedogenesis in Hawaiian basalt, Geochim. Cosmochim. Acta, 68, 4859-4876, doi:10.1016/j.gca.2004.06.005, 2004.

Chung, H., Ngo, K. J., Plante, A. and Six, J.: Evidence for Carbon Saturation in a Highly Structured and Organic-Matter-Rich Soil, Soil Sci. Soc. Am. J., 74, 130, doi:10.2136/sssaj2009.0097, 2010. 
Colin, W. J. and Reid, C.: Predicting surface area of coarse-textured soils: Implications for weathering rates, Can. J. Soil Sci., 93.5, 621-630, 2013.

Conant, R. T., Ryan, M. G., Ågren, G. I., Birge, H. E., Davidson, E. A., Eliasson, P. E., Evans, S. E., Frey, S. D., Giardina, C. P., Hopkins, F. M., Hyvönen, R., Kirschbaum, M. U. F., Lavallee, J. M., Leifeld, J., Parton, W. J., Megan Steinweg, J., Wallenstein, M. D., Martin Wetterstedt, J. A. and Bradford, M. A.: Temperature and soil organic matter decomposition rates - synthesis of current knowledge and a way forward, Glob. Chang. Biol., 17(11), 3392-3404, doi:10.1111/j.1365-2486.2011.02496.x, 2011.

Cotrufo, M. F., Wallenstein, M. D., Boot, C. M., Denef, K. and Paul, E.: The Microbial Efficiency-Matrix Stabilization (MEMS) framework integrates plant litter decomposition with soil organic matter stabilization: do labile plant inputs form stable soil organic matter?, Glob. Chang. Biol., 19(4), 988-95, doi:10.1111/gcb.12113, 2013.

Curtis, G. P.: Comparison of approaches for simulating reactive solute transport involving organic degradation reactions by multiple terminal electron acceptors, Comput. Geosci., 29(3), 319-329, doi:10.1016/S0098-3004(03)00008-6, 2003.

Davidson, E. A. and Janssens, I. A.: Temperature sensitivity of soil carbon decomposition and feedbacks to climate change., Nature, 440, 165-173, doi:10.1038/nature04514, 2006.

Davis, J. A. and Kent, D. B.: Surface complexation modeling in aqueous geochemistry, Rev. Mineral., 23, 176-260 [online] Available from: Volltext nur via Bestellung, 1990.

Davis, J. and Coston, J.: Application of the surface complexation concept to complex mineral assemblages, Environ. Sci. Technol., (d), 2820-2828 [online] Available from: http://pubs.acs.org/doi/abs/10.1021/es980312q (Accessed 1 October 2014), 1998.

DeAngelis, K. M., Chivian, D., Fortney, J. L., Arkin, A. P., Simmons, B., Hazen, T. C. and Silver, W. L.: Changes in microbial dynamics during long-term decomposition in tropical forests, Soil Biol. Biochem., 66, 60-68, doi:10.1016/j.soilbio.2013.06.010, 2013.

Dudal, Y. and Gérard, F.: Accounting for natural organic matter in aqueous chemical equilibrium models: A review of the theories and applications, Earth-Science Rev., 66, 199-216, doi:10.1016/j.earscirev.2004.01.002, 2004.

Dungait, J. A. J., Hopkins, D. W., Gregory, A. S. and Whitmore, A. P.: Soil organic matter turnover is governed by accessibility not recalcitrance, Glob. Chang. Biol., 18, 1781-1796, doi:10.1111/j.1365-2486.2012.02665.x, 2012.

Dzombak, D. A.: Surface Complexation Modeling: Hydrous Ferric Oxide, John Wiley \& Sons. [online] Available from:

http://books.google.com/books?hl=en\&lr=\&id=LGBtoHNUbWwC\&pgis=1 (Accessed 18 November 2014), 1990.

Feller, C., Schouller, E., Thomas, F., Rouiller, J. and Herbillon, A. J.: N2-Bet Specific Surface Areas of Some Low Activity Clay Soils and Their Relationships With Secondary Constituents and Organic Matter Contents, Soil Sci., 153(4), 293-299, doi:10.1097/00010694-199204000-00005, 1992.

Frei, S., Knorr, K. H., Peiffer, S. and Fleckenstein, J. H.: Surface micro-topography 
causes hot spots of biogeochemical activity in wetland systems: A virtual modeling experiment, J. Geophys. Res. Biogeosciences, 117, doi:10.1029/2012JG002012, 2012.

Frolov, A. V.: Estimation of the statistical characteristics of long-term fluctuations in evaporation from large river catchments, Dokl. Earth Sci., 458(1), 1183-1186, doi:10.1134/S1028334X1409027X, 2014.

Frostegard, A. and Baath, E.: The use of phospholipid fatty acid analysis to estimate bacterial and fungal biomass in soil, Biol. Fertil. Soils, 22, 59-65, doi:10.1007/BF00384433, 1996.

van Genuchten, M. T.: A Closed-form Equation for Predicting the Hydraulic Conductivity of Unsaturated Soils1, Soil Sci. Soc. Am. J., 44, 892, doi:10.2136/sssaj1980.03615995004400050002x, 1980.

German, D. P., Marcelo, K. R. B., Stone, M. M. and Allison, S. D.: The MichaelisMenten kinetics of soil extracellular enzymes in response to temperature: a crosslatitudinal study, Glob. Chang. Biol., 18(4), 1468-1479, doi:10.1111/j.13652486.2011.02615.x, 2012.

Gjettermann, B., Styczen, M., Hansen, H. C. B., Vinther, F. P. and Hansen, S.: Challenges in modelling dissolved organic matter dynamics in agricultural soil using DAISY, Soil Biol. Biochem., 40, 1506-1518, doi:10.1016/j.soilbio.2008.01.005, 2008.

Goldberg, S., Criscenti, L. J., Turner, D. R., Davis, J. a. and Cantrell, K. J.: AdsorptionDesorption Processes in Subsurface Reactive Transport Modeling, Vadose Zo. J., 6(3), 407, doi:10.2136/vzj2006.0085, 2007.

Goldfarb, K. C., Karaoz, U., Hanson, C. A., Santee, C. A., Bradford, M. A., Treseder, K. K., Wallenstein, M. D. and Brodie, E. L.: Differential growth responses of soil bacterial taxa to carbon substrates of varying chemical recalcitrance, Front. Microbiol., 2, doi:10.3389/fmicb.2011.00094, 2011.

Gottschalk, P., Smith, J. U., Wattenbach, M., Bellarby, J., Stehfest, E., Arnell, N., Osborn, T. J., Jones, C. and Smith, P.: How will organic carbon stocks in mineral soils evolve under future climate? Global projections using RothC for a range of climate change scenarios, Biogeosciences, 9, 3151-3171, doi:10.5194/bg-9-3151-2012, 2012.

Grant, R. F., Black, T. A., Gaumont-Guay, D., Klujn, N., Barr, A. G., Morgenstern, K. and Nesic, Z.: Net ecosystem productivity of boreal aspen forests under drought and climate change: Mathematical modelling with Ecosys, Agric. For. Meteorol., 140, 152170, doi:10.1016/j.agrformet.2006.01.012, 2006.

Greenland, D. J.: Interactions between humic and fulvic acids and clays, Soil Sci. [online] Available from: http://agris.fao.org/agris-search/search.do?recordID=US201302364487 (Accessed 1 October 2014), 1971.

Gu, B. H., Schmitt, J., Chen, Z. H., Liang, L. Y. and McCarthy, J. F.: Adsorption and Desorption of Natural Organic-Matter on Iron-Oxide - Mechanisms and Models, Environ. Sci. Technol., 28, 38-46, doi:10.1021/es00050a007, 1994.

Guenet, B., Eglin, T., Vasilyeva, N., Peylin, P., Ciais, P. and Chenu, C.: The relative 
importance of decomposition and transport mechanisms in accounting for soil organic carbon profiles, Biogeosciences, 10(4), 2379-2392, doi:10.5194/bg-10-2379-2013, 2013.

Guggenberger, G. and Kaiser, K.: Dissolved organic matter in soil: Challenging the paradigm of sorptive preservation, in Geoderma, vol. 113, pp. 293-310., 2003.

Hassink, J. and Whitmore, A. P.: A Model of the Physical Protection of Organic Matter in Soils, Soil Sci. Soc. Am. J., 61(1), 131, doi:10.2136/sssaj1997.03615995006100010020x, 1997.

He, Y., Yang, J., Zhuang, Q., McGuire, A. D., Zhu, Q., Liu, Y. and Teskey, R. O.: Uncertainty in the fate of soil organic carbon: A comparison of three conceptually different decomposition models at a larch plantation, J. Geophys. Res. Biogeosciences, 119(9), 1892-1905, doi:10.1002/2014JG002701, 2014.

Hiemstra, T., De Wit, J. C. . and Van Riemsdijk, W. .: Multisite proton adsorption modeling at the solid/solution interface of (hydr)oxides: A new approach, J. Colloid Interface Sci., 133, 105-117, doi:10.1016/0021-9797(89)90285-3, 1989.

Hodson, M. E., Langan, S. J., Kennedy, F. M. and Bain, D. C.: Variation in soil surface area in a chronosequence of soils from Glen Feshie, Scotland and its implications for mineral weathering rate calculations, Geoderma, 85(1), 1-18, doi:10.1016/S00167061(98)00013-5, 1998.

Holub, S. M., Lajtha, K., Spears, J. D. H., Tóth, J. A., Crow, S. E., Caldwell, B. A., Papp, M. and Nagy, P. T.: Organic matter manipulations have little effect on gross and net nitrogen transformations in two temperate forest mineral soils in the USA and central Europe, For. Ecol. Manage., 214, 320-330, doi:10.1016/j.foreco.2005.04.016, 2005.

Jagadamma, S., Mayes, M. A. and Phillips, J. R.: Selective Sorption of Dissolved Organic Carbon Compounds by Temperate Soils, PLoS One, 7, doi:10.1371/journal.pone.0050434, 2012.

Jardine, P. M., Mayes, M. A., Mulholland, P. J., Hanson, P. J., Tarver, J. R., Luxmoore, R. J., McCarthy, J. F. and Wilson, G. V.: Vadose Zone Flow and Transport of Dissolved Organic Carbon at Multiple Scales in Humid Regimes, Vadose Zo. J., 5, 140, doi:10.2136/vzj2005.0036, 2006.

Jardine, P. M., McCarthy, J. F. and Weber, N. L.: Mechanisms of Dissolved Organic Carbon Adsorption on Soil, Soil Sci. Soc. Am. J., 53(5), 1378, doi:10.2136/sssaj1989.03615995005300050013x, 1989.

Jardine, P. M., Wilson, G. V., McCarthy, J. F., Luxmoore, R. J., Taylor, D. L. and Zelazny, L. W.: Hydrogeochemical processes controlling the transport of dissolved organic carbon through a forested hillslope, J. Contam. Hydrol., 6, 3-19, doi:10.1016/0169-7722(90)90008-5, 1990.

Jenkinson, D. S. and Coleman, K.: The turnover of organic carbon in subsoils. Part 2. Modelling carbon turnover, Eur. J. Soil Sci., 59, 400-413, doi:10.1111/j.13652389.2008.01026.x, 2008.

Jobbágy, E. G. and Jackson, R. B.: The vertical distribution of soil organic carbon and its 
relation to climate and vegetation, Ecol. Appl., 10(2), 423-436, doi:10.1890/10510761(2000)010[0423:TVDOSO]2.0.CO;2, 2000.

Kaiser, K. and Guggenberger, G.: Mineral surfaces and soil organic matter, Eur. J. Soil Sci., 54(2), 219-236, doi:10.1046/j.1365-2389.2003.00544.x, 2003.

Kalbitz, K., Schmerwitz, J., Schwesig, D. and Matzner, E.: Biodegradation of soilderived dissolved organic matter as related to its properties, in Geoderma, vol. 113, pp. 273-291., 2003.

Kalbitz, K., Solinger, S., Park, J.-H., Michalzik, B. and Matzner, E.: Controls on the dynamics of dissolved organic matter in soils: a review, Soil Sci., 165, 277-304, doi:10.1097/00010694-200004000-00001, 2000.

Kögel-Knabner, I.: The macromolecular organic composition of plant and microbial residues as inputs to soil organic matter, Soil Biol. Biochem., 34(2), 139-162, doi:10.1016/S0038-0717(01)00158-4, 2002.

Kothawala, D. N. and Moore, T. R.: Adsorption of dissolved nitrogen by forest mineral soils, Can. J. For. Res., 39, 2381-2390, doi:10.1139/X09-147, 2009.

Kothawala, D. N., Moore, T. R. and Hendershot, W. H.: Adsorption of dissolved organic carbon to mineral soils: A comparison of four isotherm approaches, Geoderma, 148, 4350, doi:10.1016/j.geoderma.2008.09.004, 2008.

Kothawala, D. N., Moore, T. R. and Hendershot, W. H.: Soil Properties Controlling the Adsorption of Dissolved Organic Carbon to Mineral Soils, Soil Sci. Soc. Am. J., 73, 1831, doi:10.2136/sssaj2008.0254, 2009.

Koven, C. D., Riley, W. J., Subin, Z. M., Tang, J. Y., Torn, M. S., Collins, W. D., Bonan, G. B., Lawrence, D. M. and Swenson, S. C.: The effect of vertically resolved soil biogeochemistry and alternate soil $\mathrm{C}$ and $\mathrm{N}$ models on C dynamics of CLM4, Biogeosciences, 10(11), 7109-7131, doi:10.5194/bg-10-7109-2013, 2013.

Lawrence, C. R., Neff, J. C. and Schimel, J. P.: Does adding microbial mechanisms of decomposition improve soil organic matter models? A comparison of four models using data from a pulsed rewetting experiment, Soil Biol. Biochem., 41(9), 1923-1934, doi:10.1016/j.soilbio.2009.06.016, 2009.

Lawrence, D. M., Oleson, K. W., Flanner, M. G., Thornton, P. E., Swenson, S. C., Lawrence, P. J., Zeng, X., Yang, Z.-L., Levis, S., Sakaguchi, K., Bonan, G. B. and Slater, A. G.: Parameterization improvements and functional and structural advances in Version 4 of the Community Land Model, J. Adv. Model. Earth Syst., 3(1), n/a-n/a, doi:10.1029/2011MS00045, 2011.

Leifeld, J., Zimmermann, M., Fuhrer, J. and Conen, F.: Storage and turnover of carbon in grassland soils along an elevation gradient in the Swiss Alps, Glob. Chang. Biol., 15, 668-679, doi:10.1111/j.1365-2486.2008.01782.x, 2009.

Lenhart, J. J. and Honeyman, B. D.: Uranium(VI) sorption to hematite in the presence of humic acid, Geochim. Cosmochim. Acta, 63(19-20), 2891-2901, doi:10.1016/S00167037(99)00269-0, 1999. 
Levin, I. and Hesshaimer, V.: Radiocarbon - a Unique Tracer of Global Carbon Cycle Dynamics, Radiocarbon, 42, 69-80, doi:10.2458/azu_js_rc.42.3855, 2000.

Levin, I. and Kromer, B.: The Tropospheric 14CO2 Level In Mid-Latitudes of The Northern Hemisphere (1959-2003), Radiocarbon, 46, 1261-1272 [online] Available from: https://journals.uair.arizona.edu/index.php/radiocarbon/article/view/4181, 2004.

Li, F., Kustas, W. P., Anderson, M. C., Prueger, J. H. and Scott, R. L.: Effect of remote sensing spatial resolution on interpreting tower-based flux observations, Remote Sens. Environ., 112, 337-349, doi:10.1016/j.rse.2006.11.032, 2008.

Luo, Z., Wang, E., Zheng, H., Baldock, J. A., Sun, O. J. and Shao, Q.: Convergent modelling of past soil organic carbon stocks but divergent projections, Biogeosciences, 12(14), 4373-4383, doi:10.5194/bg-12-4373-2015, 2015.

Lutzow, M. v., Kogel-Knabner, I., Ekschmitt, K., Matzner, E., Guggenberger, G., Marschner, B. and Flessa, H.: Stabilization of organic matter in temperate soils: mechanisms and their relevance under different soil conditions - a review, Eur. J. Soil Sci., 57(4), 426-445, doi:10.1111/j.1365-2389.2006.00809.x, 2006.

Maggi, F. and Riley, W. J.: Mathematical treatment of isotopologue and isotopomer speciation and fractionation in biochemical kinetics, Geochim. Cosmochim. Acta, 74(6), 1823-1835, doi:10.1016/j.gca.2009.12.021, 2010.

Maher, K., Steefel, C. I., White, A. F. and Stonestrom, D. A.: The role of reaction affinity and secondary minerals in regulating chemical weathering rates at the Santa Cruz Soil Chronosequence, California, Geochim. Cosmochim. Acta, 73, 2804-2831, doi:10.1016/j.gca.2009.01.030, 2009.

Masiello, C. A., Chadwick, O. A., Southon, J., Torn, M. S. and Harden, J. W.: Weathering controls on mechanisms of carbon storage in grassland soils, Global Biogeochem. Cycles, 18, 1-9, doi:10.1029/2004GB002219, 2004.

Mayer, L. M.: Relationships between mineral surfaces and organic carbon concentrations in soils and sediments, Chem. Geol., 114, 347-363, doi:10.1016/0009-2541(94)90063-9, 1994a.

Mayer, L. M.: Relationships between mineral surfaces and organic carbon concentrations in soils and sediments, Chem. Geol., 114(3-4), 347-363, doi:10.1016/00092541(94)90063-9, 1994b.

Mayes, M. A., Heal, K. R., Brandt, C. C., Phillips, J. R. and Jardine, P. M.: Relation between Soil Order and Sorption of Dissolved Organic Carbon in Temperate Subsoils, Soil Sci. Soc. Am. J., 76, 1027, doi:10.2136/sssaj2011.0340, 2012.

Merritts, D. J., Chadwick, O. A. and Hendricks, D. M.: Rates and processes of soil evolution on uplifted marine terraces, northern California, Geoderma, 51, 241-275, doi:10.1016/0016-7061(91)90073-3, 1991.

Molins, S., Trebotich, D., Steefel, C. I. and Shen, C.: An investigation of the effect of pore scale flow on average geochemical reaction rates using direct numerical simulation, Water Resour. Res., 48, doi:10.1029/2011WR011404, 2012. 
Moore, T. R. and Turunen, J.: Carbon Accumulation and Storage in Mineral Subsoil beneath Peat, Soil Sci. Soc. Am. J., 68, 690, doi:10.2136/sssaj2004.0690, 2004.

Murphy, R. J., Lenhart, J. J. and Honeyman, B. D.: The sorption of thorium (IV) and uranium (VI) to hematite in the presence of natural organic matter, Colloids Surfaces A Physicochem. Eng. Asp., 157(1-3), 47-62, doi:10.1016/S0927-7757(99)00115-6, 1999.

Neely, C. L., Beare, M. H., Hargrove, W. L. and Coleman, D. C.: Relationships between fungal and bacterial substrate-induced respiration, biomass and plant residue decomposition, Soil Biol. Biochem., 23, 947-954, doi:10.1016/0038-0717(91)90175-J, 1991.

Parton, W. J., Hanson, P. J., Swanston, C., Torn, M., Trumbore, S. E., Riley, W. and Kelly, R.: ForCent model development and testing using the Enriched Background Isotope Study experiment, J. Geophys. Res. Biogeosciences, 115, doi:10.1029/2009JG001193, 2010.

Parton, W. J., Schimel, D. S., Cole, C. V. and Ojima, D. S.: Analysis of Factors Controlling Soil Organic Matter Levels in Great Plains Grasslands1, Soil Sci. Soc. Am. J., 51(5), 1173, doi:10.2136/sssaj1987.03615995005100050015x, 1987.

Pau, G. S. H., Shen, C., Riley, W. J. and Liu, Y.: Accurate and efficient prediction of fine-resolution hydrologic and carbon dynamic simulations from coarse-resolution models, Water Resour. Res., 52(2), 791-812, doi:10.1002/2015WR017782, 2016.

Pruess, K.: TOUGH2 User's Guide Version 2, Lawrence Berkeley Natl. Lab., 210 [online] Available from: http://escholarship.org/uc/item/4df6700h.pdf, 1999.

Reed, M. H.: Calculation of multicomponent chemical equilibria and reaction processes in systems involving minerals, gases and an aqueous phase, Geochim. Cosmochim. Acta, 46, 513-528, doi:10.1016/0016-7037(82)90155-7, 1982.

Riley, W. J., Maggi, F., Kleber, M., Torn, M. S., Tang, J. Y., Dwivedi, D. and Guerry, N.: Long residence times of rapidly decomposable soil organic matter: application of a multi-phase, multi-component, and vertically resolved model (BAMS1) to soil carbon dynamics, Geosci. Model Dev., 7(4), 1335-1355, doi:10.5194/gmd-7-1335-2014, 2014.

Riley, W. J. and Shen, C.: Characterizing coarse-resolution watershed soil moisture heterogeneity using fine-scale simulations, Hydrol. Earth Syst. Sci., 18(7), 2463-2483, doi:10.5194/hess-18-2463-2014, 2014.

Romaní, A. M., Fischer, H., Mille-Lindblom, C. and Tranvik, L. J.: Interactions of bacteria and fungi on decomposing litter: Differential extracellular enzyme activities, Ecology, 87, 2559-2569, doi:10.1890/0012-9658(2006)87[2559:IOBAFO]2.0.CO;2, 2006.

Sahai, N. and Sverjensky, D. A.: Evaluation of internally consistent parameters for the triple-layer model by the systematic analysis of oxide surface titration data, Geochim. Cosmochim. Acta, 61, 2801-2826, doi:10.1016/S0016-7037(97)00128-2, 1997a.

Sahai, N. and Sverjensky, D. A.: Solvation and electrostatic model for specific electrolyte adsorption, Geochim. Cosmochim. Acta, 61, 2827-2848, doi:10.1016/S0016- 
7037(97)00127-0, 1997b.

Sanderman, J., Baldock, J. A. and Amundson, R.: Dissolved organic carbon chemistry and dynamics in contrasting forest and grassland soils, Biogeochemistry, 89, 181-198, doi:10.1007/s10533-008-9211-x, 2008.

Schenk, H. J. and Jackson, R. B.: The global biogeography of roots, Ecol. Monogr., 72, 311-328, doi:10.1890/0012-9615(2002)072[0311:TGBOR]2.0.CO;2, 2002.

Schenk, H. J. and Jackson, R. B.: Mapping the global distribution of deep roots in relation to climate and soil characteristics, Geoderma, 126, 129-140, doi:10.1016/j.geoderma.2004.11.018, 2005.

Schimel, J. P., Wetterstedt, J. Å. M., Holden, P. A. and Trumbore, S. E.: Drying/rewetting cycles mobilize old $\mathrm{C}$ from deep soils from a California annual grassland, Soil Biol. Biochem., 43(5), 1101-1103, doi:10.1016/j.soilbio.2011.01.008, 2011.

Schmidt, M. W. I., Torn, M. S., Abiven, S., Dittmar, T., Guggenberger, G., Janssens, I. A., Kleber, M., Kögel-Knabner, I., Lehmann, J., Manning, D. A. C., Nannipieri, P., Rasse, D. P., Weiner, S. and Trumbore, S. E.: Persistence of soil organic matter as an ecosystem property, Nature, 478, 49-56, doi:10.1038/nature10386, 2011.

Sibanda, H. M. and Young, S. D.: Competitive adsorption of humus acids and phosphate on goethite, gibbsite and two tropical soils, J. Soil Sci., 37(2), 197-204, doi:10.1111/j.1365-2389.1986.tb00020.x, 1986.

Sivapalan, M.: Pattern, Process and Function: Elements of a Unified Theory of Hydrology at the Catchment Scale, in Encyclopedia of Hydrological Sciences, pp. 193219., 2005.

Six, J., Bossuyt, H., Degryze, S. and Denef, K.: A history of research on the link between (micro)aggregates, soil biota, and soil organic matter dynamics, Soil Tillage Res., 79, 7 31, doi:10.1016/j.still.2004.03.008, 2004.

Six, J., Conant, R. T., Paul, E. A. and Paustian, K.: Stabilization mechanisms of soil organic matter: Implications for C-saturation of soils, Plant Soil, 241, 155-176, doi:10.1023/A:1016125726789, 2002.

Six, J., Elliott, E. T. and Paustian, K.: Soil Structure and Soil Organic Matter: II. A Normalized Stability Index and the Effect of Mineralogy, Soil Sci. Soc. Am., 64, 10421049, doi:10.2136/sssaj2000.6431042x, 2000.

Sollins, P., Homann, P. and Caldwell, B. A.: Stabilization and destabilization of soil organic matter: Mechanisms and controls, Geoderma, 74(1-2), 65-105, doi:10.1016/S0016-7061(96)00036-5, 1996.

Steefel, C. I. and Lasaga, A. C.: A coupled model for transport of multiple chemical species and kinetic precipitation/dissolution reactions with application to reactive flow in single phase hydrothermal systems, Am. J. Sci., 294, 529-592,

doi:10.2475/ajs.294.5.529, 1994.

Stewart, C. E., Paustian, K., Conant, R. T., Plante, A. F. and Six, J.: Soil carbon 
saturation: Implications for measurable carbon pool dynamics in long-term incubations, Soil Biol. Biochem., 41, 357-366, doi:10.1016/j.soilbio.2008.11.011, 2009.

Stuiver, M. and Polach, H. A.: Radiocarbon., 1999.

Sulman, B. N., Oishi, C., A., Phillips, R. P., E., S. and S., P.: Microbe-driven turnover offsets mineral-mediated storage of soil carbon under elevated CO2, Nat. Clim. Chang., 4, 1099-1102, doi:10.1038/nclimate2436, 2014.

Tang, J. and Riley, W. J.: Impacts of a new bare-soil evaporation formulation on site, regional, and global surface energy and water budgets in CLM4, J. Adv. Model. Earth Syst., 5(3), 558-571, doi:10.1002/jame.20034, 2013.

Tang, J. and Riley, W. J.: Weaker Carbon-climate Feedbacks Resulting from Microbial and Abiotic Interactions, Nat. Clim. Chang., 2014.

Tang, J. Y., Riley, W. J., Koven, C. D. and Subin, Z. M.: CLM4-BeTR, a generic biogeochemical transport and reaction module for CLM4: model development, evaluation, and application, Geosci. Model Dev., 6(1), 127-140, doi:10.5194/gmd-6-1272013, 2013.

Thevenot, M., Dignac, M. F. and Rumpel, C.: Fate of lignins in soils: A review, Soil Biol. Biochem., 42, 1200-1211, doi:10.1016/j.soilbio.2010.03.017, 2010.

Torn, M. S., Lapenis, A. G., Timofeev, A., Fischer, M. L., Babikov, B. V. and Harden, J. W.: Organic carbon and carbon isotopes in modern and 100-year-old-soil archives of the Russian steppe, Glob. Chang. Biol., 8, 941-953, doi:10.1046/j.1365-2486.2002.00477.x, 2002.

Torn, M. S., Swanston, C. W., Castanha, C. and Trumbore, S.: Storage and turnover of natural organic matter in soil., IUPAC Seri., edited by N. Senesi, B. Xing, and P. M. Huang. [online] Available from: http://www.wiley.com/WileyCDA/WileyTitle/productCd-047041300X.html (Accessed 11 June 2015), 2009.

Torn, M. S., Trumbore, S. E., Chadwick, O. A., Vitousek, P. M. and Hendricks, D. M.: Mineral control of soil organic carbon storage and turnover, Nature, 389, 170-173, doi:10.1038/38260, 1997a.

Torn, M. S., Trumbore, S. E., Chadwick, O. A., Vitousek, P. M. and Hendricks, D. M.: Mineral control of soil organic carbon storage and turnover, Nature, 389, 170-173, doi:doi:10.1038/38260, 1997b.

Trumbore, S.: Age of soil organic matter and soil respiration: Radiocarbon constraints on belowground C dynamics, Ecol. Appl., 10, 399-411, doi:10.1890/1051-

0761(2000)010[0399:AOSOMA]2.0.CO;2, 2000.

Trumbore, S.: Radiocarbon and Soil Carbon Dynamics, Annu. Rev. Earth Planet. Sci., 37, 47-66, doi:10.1146/annurev.earth.36.031207.124300, 2009.

Trumbore, S. E.: Potential responses of soil organic carbon to global environmental change, Proc. Natl. Acad. Sci., 94, 8284-8291, doi:10.1073/pnas.94.16.8284, 1997. 
Turner, D. P., Ollinger, S., Smith, M. -1., Krankina, O. and Gregory, M.: Scaling net primary production to a MODIS footprint in support of Earth observing system product validation, Int. J. Remote Sens., 25, 1961-1979, doi:10.1080/0143116031000150013, 2004.

Vanwalleghem, T., Stockmann, U., Minasny, B. and McBratney, A. B.: A quantitative model for integrating landscape evolution and soil formation, J. Geophys. Res. Earth Surf., 118(2), 331-347, doi:10.1029/2011JF002296, 2013.

Wang, Y., Wang, Z. and Li, Y.: Storage/Turnover rate of inorganic carbon and its dissolvable part in the profile of saline/alkaline soils., edited by B. Bond-Lamberty, PLoS One, 8(11), e82029, doi:10.1371/journal.pone.0082029, 2013.

Wattel-Koekkoek, E. J. W. and Buurman, P.: Mean Residence Time of Kaolinite and Smectite-Bound Organic Matter in Mozambiquan Soils, Soil Sci. Soc. Am. J., 68, 154161, doi:10.2136/sssaj2004.1540, 2004.

Westall, J. C., Jones, J. D., Turner, G. D. and Zachara, J. M.: Models for Association of Metal-Ions with Heterogeneous Environmental Sorbents .1. Complexation of Co(Ii) by Leonardite Humic-Acid as a Function of Ph and Naclo4 Concentration, Environ. Sci. Technol., 29(4), 951-959, doi:10.1021/es00004a015, 1995.

White, A. F., Blum, A. E., Schulz, M. S., Bullen, T. D., Harden, J. W. and Peterson, M. L.: Chemical weathering rates of a soil chronosequence on granitic alluvium: I. Quantification of mineralogical and surface area changes and calculation of primary silicate reaction rates, Geochim. Cosmochim. Acta, 60(14), 2533-2550, doi:10.1016/0016-7037(96)00106-8, 1996.

White, A. F., Schulz, M. S., Stonestrom, D. A., Vivit, D. V., Fitzpatrick, J., Bullen, T. D., Maher, K. and Blum, A. E.: Chemical weathering of a marine terrace chronosequence, Santa Cruz, California. Part II: Solute profiles, gradients and the comparisons of contemporary and long-term weathering rates, Geochim. Cosmochim. Acta, 73, 27692803, doi:10.1016/j.gca.2009.01.029, 2009.

Xu, L., Baldocchi, D. D. and Tang, J.: How soil moisture, rain pulses, and growth alter the response of ecosystem respiration to temperature, Global Biogeochem. Cycles, 18, 110, doi:10.1029/2004GB002281, 2004.

Xu, T.: TOUGHREACT User's Guide: A Simulation Program for Non-isothermal Multiphase Reactive Geochemical Transport in Variably Saturated Geologic Media, V1.2.1, Lawrence Berkeley Natl. Lab. [online] Available from: http://escholarship.org/uc/item/9r80098d (Accessed 6 November 2015), 2008.

Xu, T., Spycher, N., Sonnenthal, E., Zhang, G., Zheng, L. and Pruess, K.: Toughreact version 2.0: A simulator for subsurface reactive transport under non-isothermal multiphase flow conditions, Comput. Geosci., 37, 763-774, doi:10.1016/j.cageo.2010.10.007, 2011.

Yeh, G. T. and Tripathi, V. S.: A model for simulating transport of reactive multispecies components: model development and demonstration, Water Resour. Res., 27, 3075-3094, doi:10.1029/91WR02028, 1991. 


\section{List of Tables}

Table 1. Parameters defining the decomposition of organic matter pools by bacteria and fungi for maximum specific consumption rate $(\boldsymbol{\mu})$, assimilation-to-respiration ratio $(\boldsymbol{e})$, and yield ( $\boldsymbol{Y})$ (modified from (Riley et al., 2014)).

Table 2. Estimated soil bulk specific surface area $\left(\mathrm{m}^{2} \mathrm{~g}_{\text {soil }}{ }^{-1}\right)$ for the two studied sites. 


\section{List of Figures}

Figure 1. Modified BAMS1 reaction Network Diagram. Bacteria and Monomers stand for heterotrophic aerobic bacteria and dissolved monomeric organic carbon, respectively; DCWM stands for "Dead Cell Wall Material".

Figure 2. Predicted and observed SOM content at the seven Chronosequence Terrace sites south of Eureka, California.

Figure 3. Predicted and observed SOM content for 3 sites in the Central Chernozem Region of Russia.

Figure 4. Predictions of modeled carbon components after 5000 years using the simulation from the CT-29ky site.

Figure 5. $\Delta^{14} \mathrm{C}$ values of total SOM at the end of 5000-year simulations (except for CT-3.9ky that is after 3900-year) at the seven Chronosequence Terrace sites south of Eureka, California.

Figure 6. ${ }^{14} \mathrm{C}$ values of total SOM at the end of 5000-year simulations at three sites in the Central Chernozem Region of Russia.

Figure 7. Predictions of $\Delta^{14} \mathrm{C}$ values of modeled carbon components at the end of a 5000-year simulation for the CT-29ky site.

Figure 8. Sensitivity of SOM profiles due to changes in (A) soil bulk specific surface area, (B) monomer sorption coefficients, (C) DCWM sorption coefficients, and (D) carbon input profiles.

Figure 9. Percent saturation of available sorption sites for various carbon input profiles.

Figure 10. Sensitivity of $\Delta^{14} \mathrm{C}$ values of total SOM to changes in the (A) soil bulk specific surface area, (B) monomer sorption coefficients, (C) DCWM sorption coefficients, and (D) carbon input profiles. 
Table 1. Parameters defining the decomposition of organic matter pools by bacteria and fungi for maximum specific consumption rate $(\boldsymbol{\mu})$, assimilation-to-respiration ratio $(\boldsymbol{e})$, and yield $(\boldsymbol{Y})$ (modified from (Riley et al., 2014)).

\begin{tabular}{|c|c|c|c|c|c|c|c|c|}
\hline & \multicolumn{3}{|c|}{ Bacteria $^{*}$} & & \multicolumn{3}{|c|}{ Fungi $^{*}$} & \\
\hline & $\begin{array}{c}\underline{\mu} \\
\left(\mathrm{s}^{-1}\right) \\
\end{array}$ & $\begin{array}{l}\underline{e} \\
\underline{(-)}\end{array}$ & $\begin{array}{c}\frac{Y}{(\mathrm{~g} \text { wet-biomass }} \\
\frac{\mathrm{mol}^{-1} \text { ) }}{}\end{array}$ & $\frac{\begin{array}{c}\underline{Y} \\
\text { (mg carbon }\end{array}}{\left.\mathrm{mg}^{-1}\right)}$ & $\begin{array}{c}\underline{\mu} \\
\left(\mathrm{s}^{-1}\right) \\
\end{array}$ & $\begin{array}{c}\underline{e} \\
\underline{(-)}\end{array}$ & $\frac{\underline{Y}}{\frac{(\mathrm{g} \text { wet-biomass }}{\mathrm{mol}^{-1} \text { ) }}}$ & $\frac{\begin{array}{c}\underline{Y} \\
\text { (mg carbon }\end{array}}{\underline{\left.\mathrm{mg}^{-1}\right)}}$ \\
\hline Organic Monomers & $2.32 \mathrm{e}-7$ & 0.08 & 67.2 & 0.3 & - & - & - & - \\
\hline Lignin & - & - & - & - & $4.20 \mathrm{e}-9$ & 0.018 & 84.0 & 0.5 \\
\hline Cellulose & - & - & - & - & $5.46 \mathrm{e}-9$ & 0.001 & 84.0 & 0.5 \\
\hline Hemicellulose & - & - & - & - & $1.68 \mathrm{e}-8$ & 0.039 & 84.0 & 0.5 \\
\hline DCWM & $3.98 \mathrm{e}-12$ & 0.018 & 48.0 & & - & - & - & - \\
\hline
\end{tabular}

${ }^{*}$ Mortality of bacteria and fungi contribute to DCWM. Biomass death rate of bacteria is $2.32 \mathrm{e}-7 \mathrm{~s}^{-1}$, and biomass death rate of fungi is 7e-9 $\mathrm{s}^{-1}$ (Riley et al., 2014). 
Table 2. Estimated soil bulk specific surface area $\left(\mathrm{m}^{2} \mathrm{~g}_{\mathrm{soil}}{ }^{-1}\right)$ for the two studied sites.

\begin{tabular}{|l|c|c|}
\hline Sites & $\begin{array}{l}\text { Soil bulk specific } \\
\text { surface area, } a_{0} \\
\left(\mathrm{~m}^{2} \mathrm{~g}_{\text {soil }}{ }^{-1}\right)\end{array}$ & $\begin{array}{l}\text { Exponential Decay } \\
\text { Constant, } z_{m} \text { (Depth } \\
\text { Profile) }\end{array}$ \\
\hline CT-3.9ky & 7.6 & 0 \\
\hline CT-29ky & 11.6 & 0.5 \\
\hline CT-40ky & $6.8-9.5$ & 0.5 \\
\hline CT-118ky & $13.5-17.4$ & 0.75 \\
\hline CT-124ky-1 & $6.8-17.4$ & 0.75 \\
\hline CT-124ky-2 & $13.5-17.4$ & 0.75 \\
\hline CT-240ky & $13.5-14.8$ & 0.75 \\
\hline Russian Steppe: Archive, Pit1, and Pit2 & 39.1 & 2.25 \\
\hline
\end{tabular}




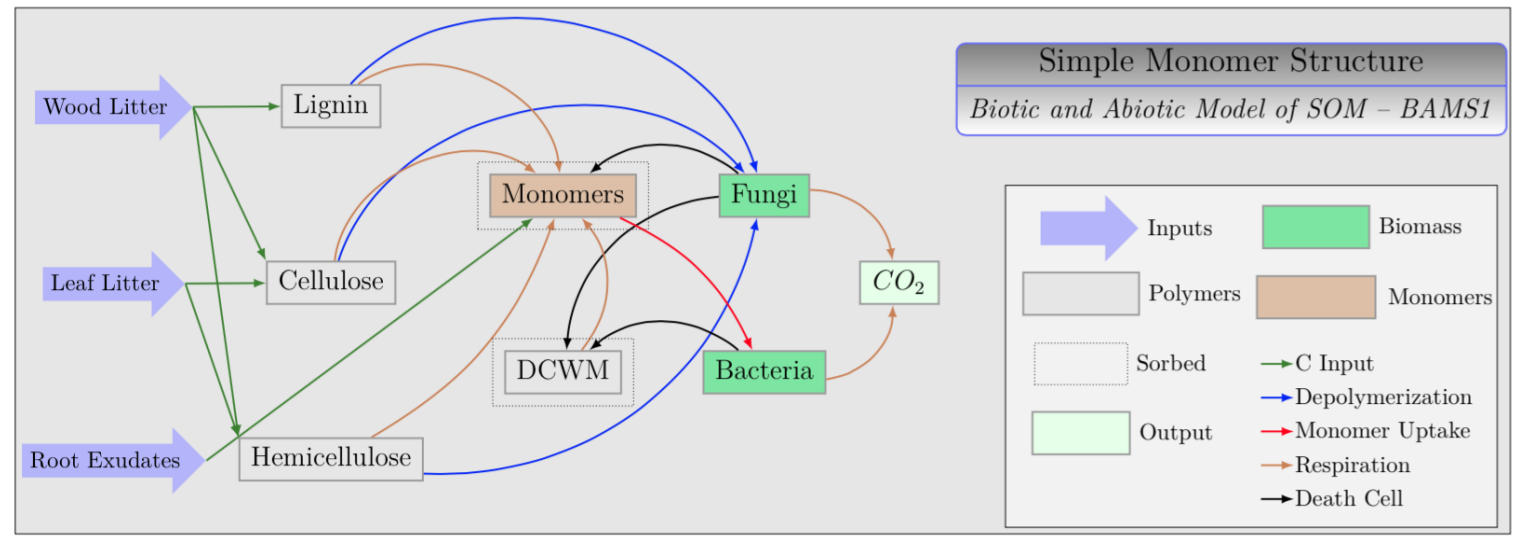

Figure 1. Modified BAMS1 reaction Network Diagram. Bacteria and Monomers stand for heterotrophic aerobic bacteria and dissolved monomeric organic carbon, respectively; DCWM stands for "Dead Cell Wall Material". 

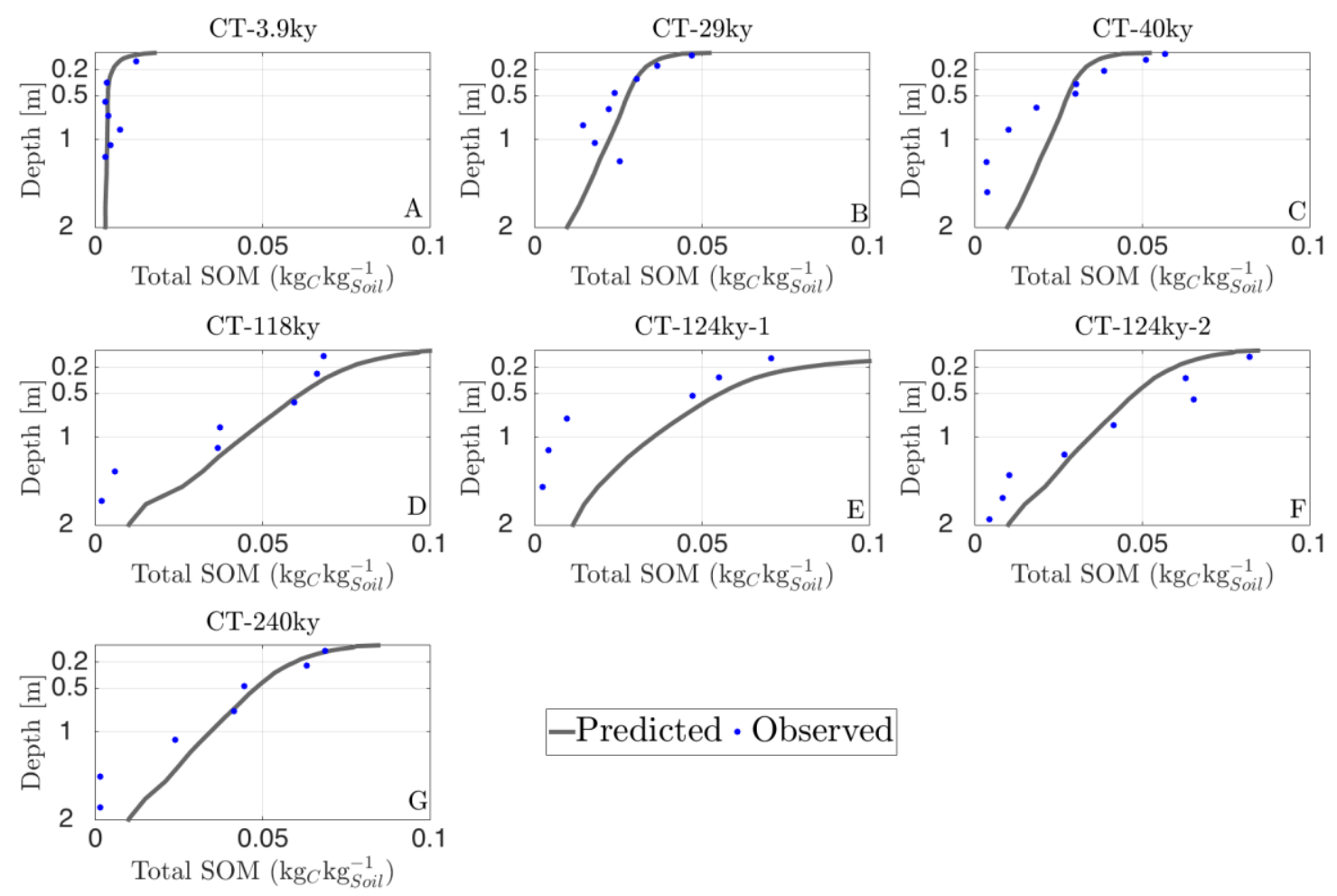

-Predicted · Observed

Figure 2. Predicted and observed SOM content at the seven Chronosequence Terrace sites south of Eureka, California. 


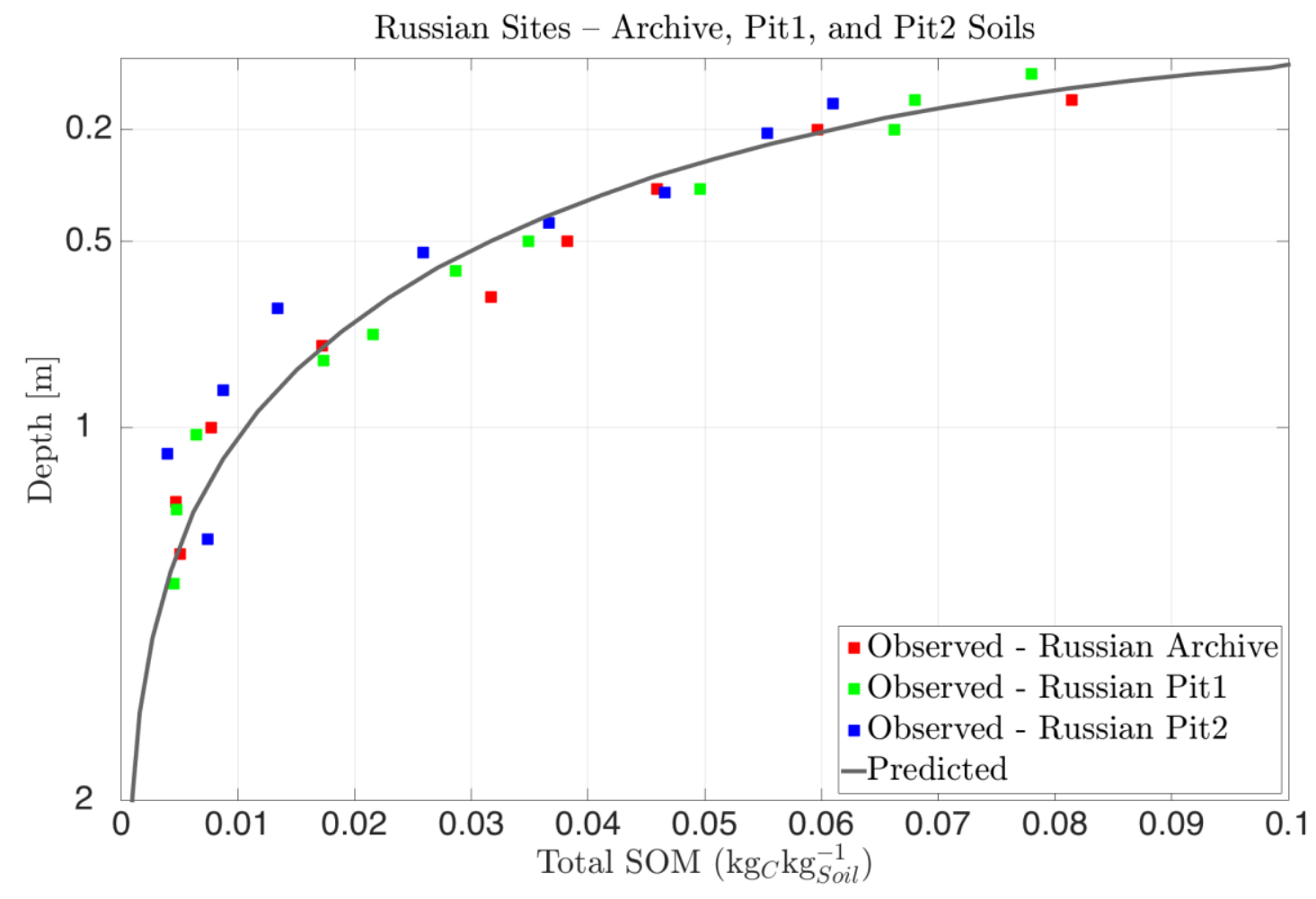

Figure 3. Predicted and observed SOM content for 3 sites in the Central Chernozem Region of Russia. 

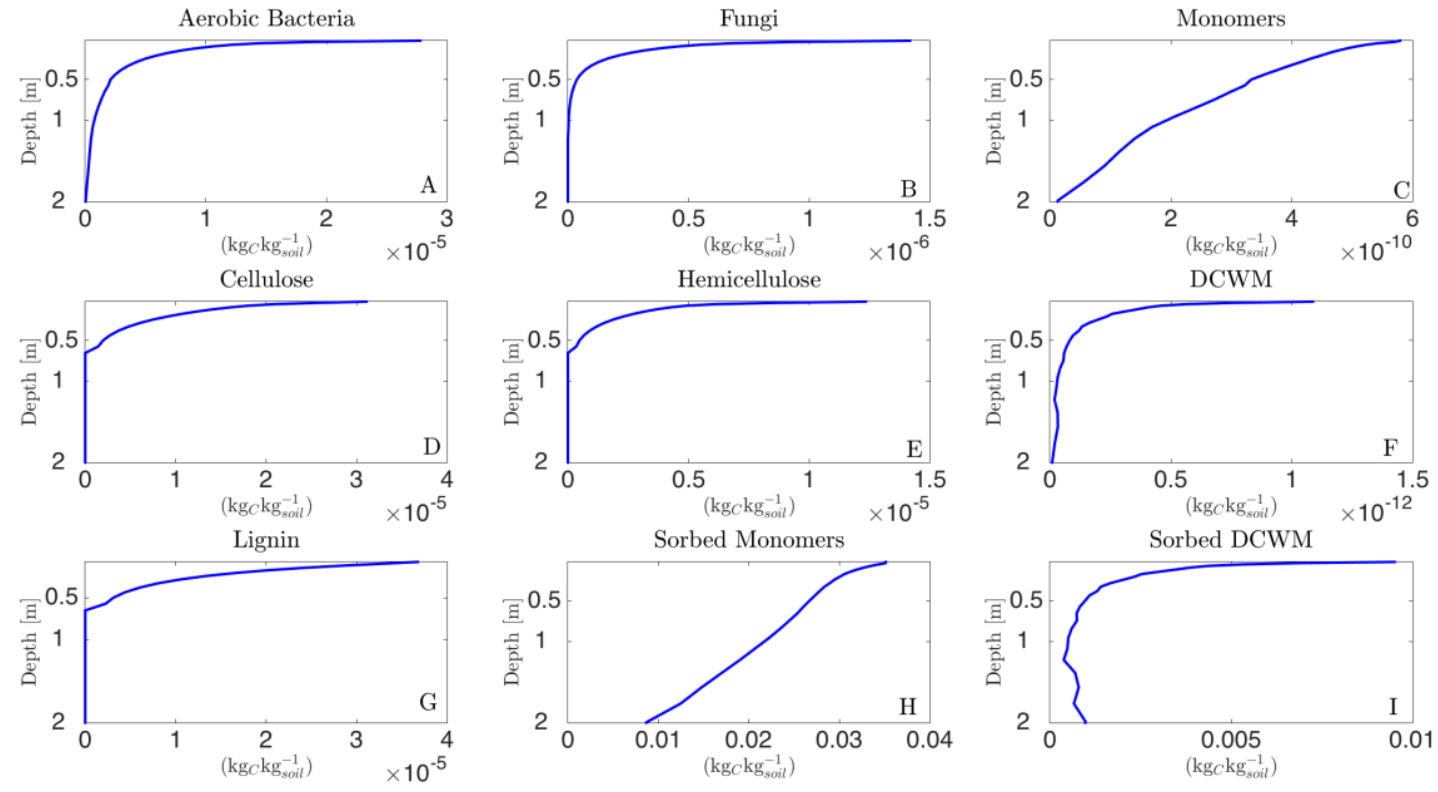

Figure 4. Predictions of modeled carbon components after 5000 years using the simulation from the CT-29ky site. 

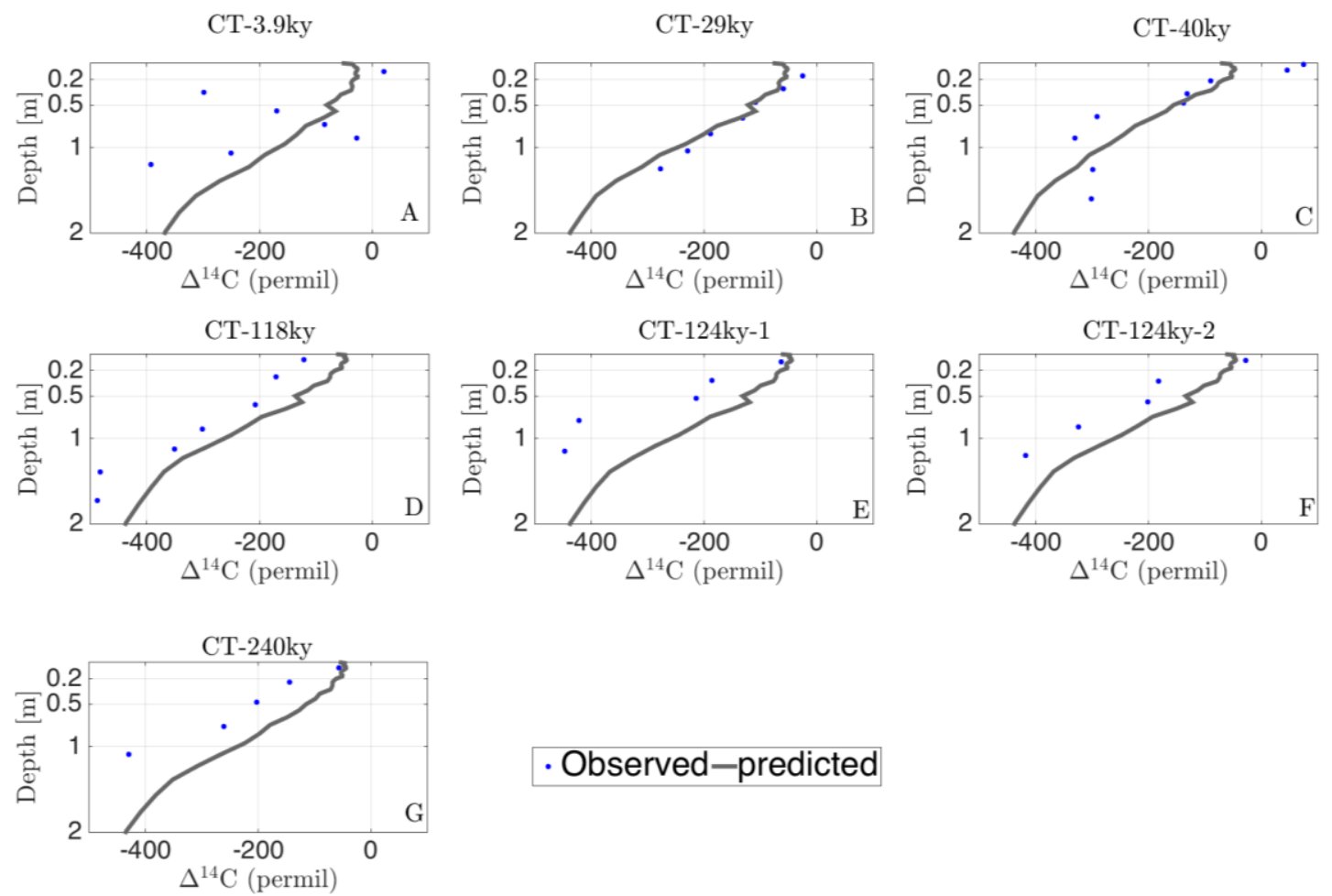

\section{- Observed-predicted}

Figure 5. $\Delta^{14} \mathrm{C}$ values of total SOM at the end of 5000-year simulations (except for CT$3.9 \mathrm{ky}$ that is after 3900-year) at the seven Chronosequence Terrace sites south of Eureka, California. 


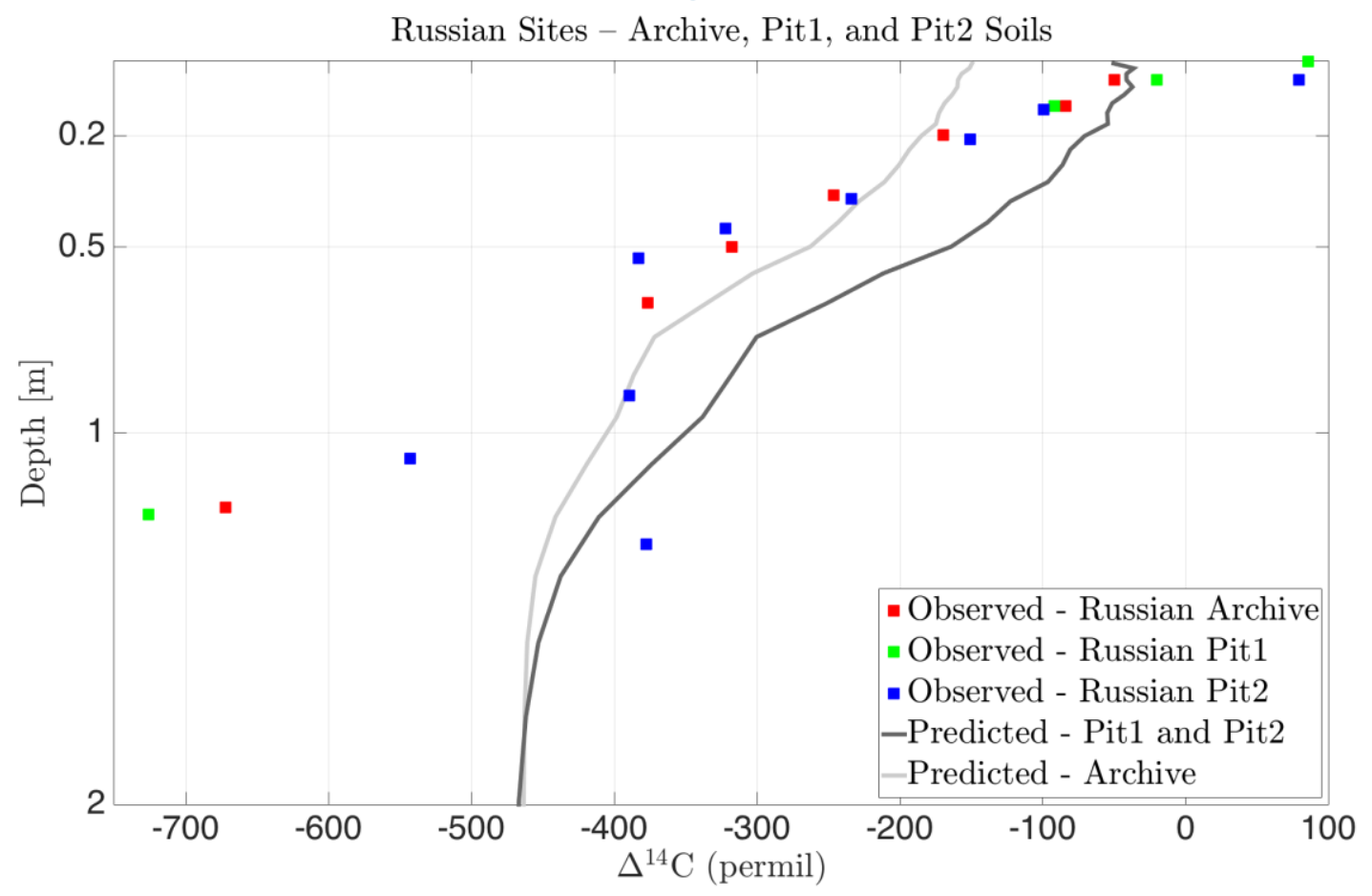

Figure 6. $\Delta^{14} \mathrm{C}$ values of total SOM at the end of 5000 -year simulations at three sites in the Central Chernozem Region of Russia. 


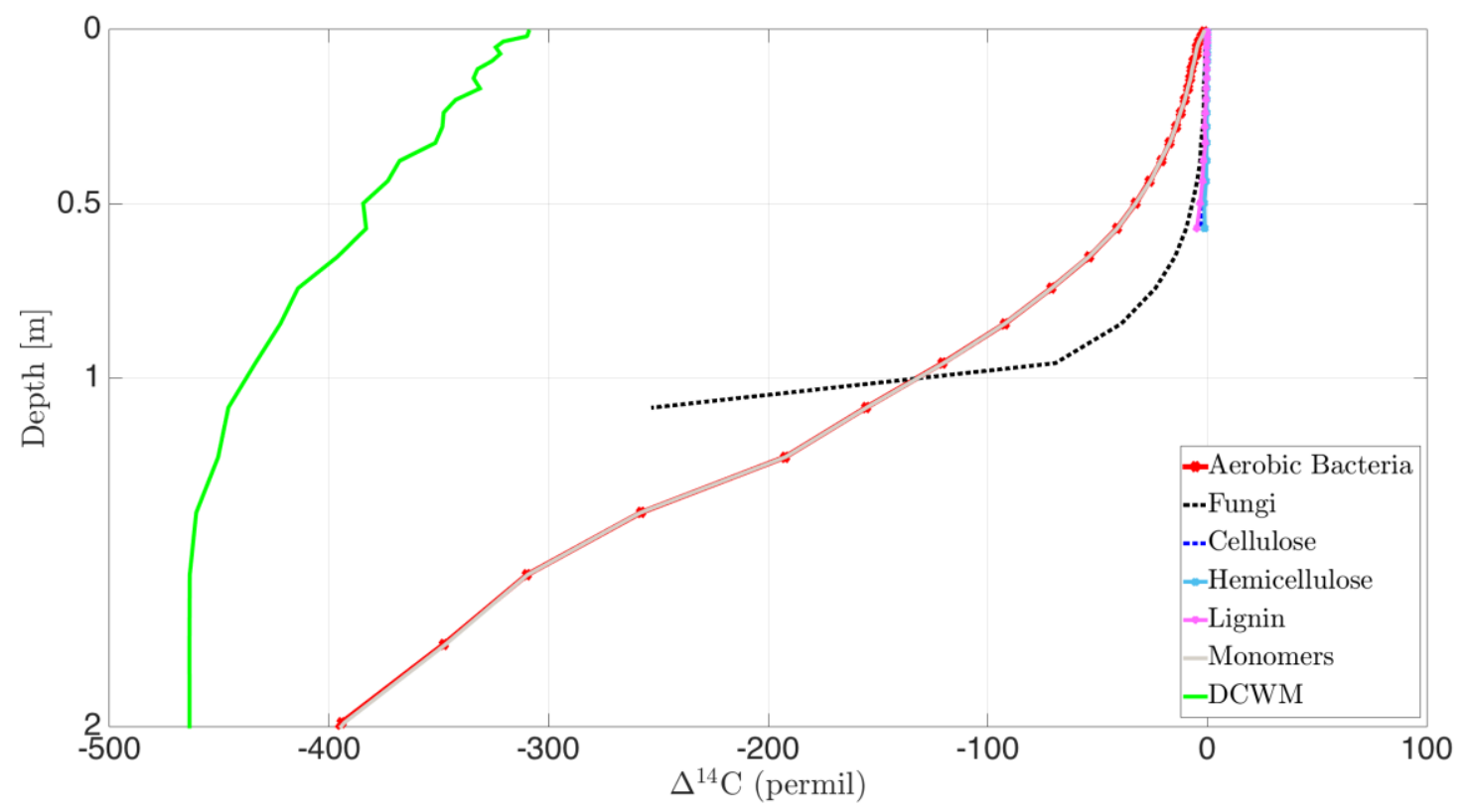

Figure 7. Predictions of $\Delta^{14} \mathrm{C}$ values of modeled carbon components at the end of a 5000-year simulation for the CT-29ky site. 

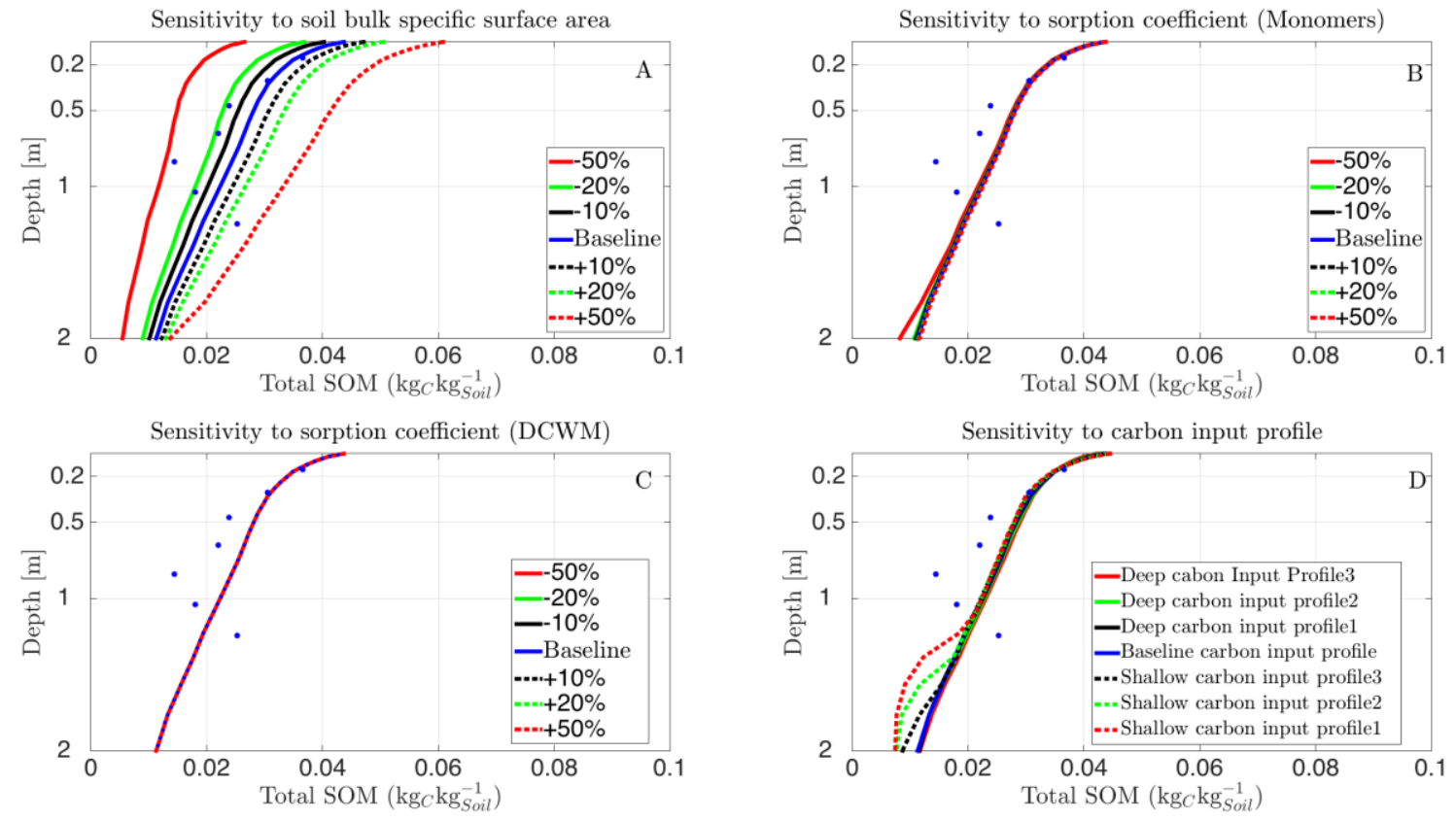

Figure 8. Sensitivity of SOM profiles due to changes in (A) soil bulk specific surface area, (B) monomer sorption coefficients, (C) DCWM sorption coefficients, and (D) carbon input profiles. 
Percent saturation of all available sorption sites

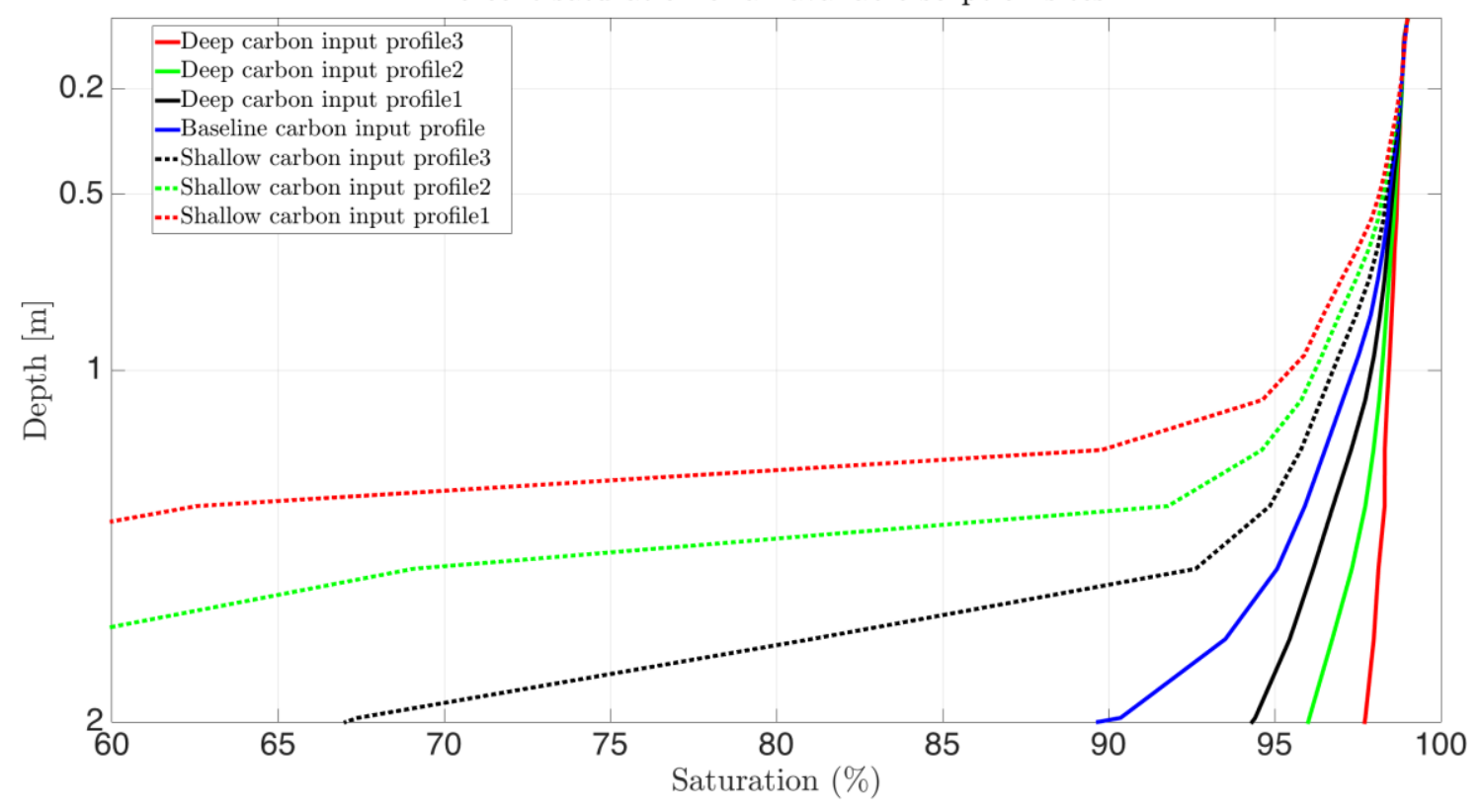

Figure 9. Percent saturation of available sorption sites for various carbon input profiles. 

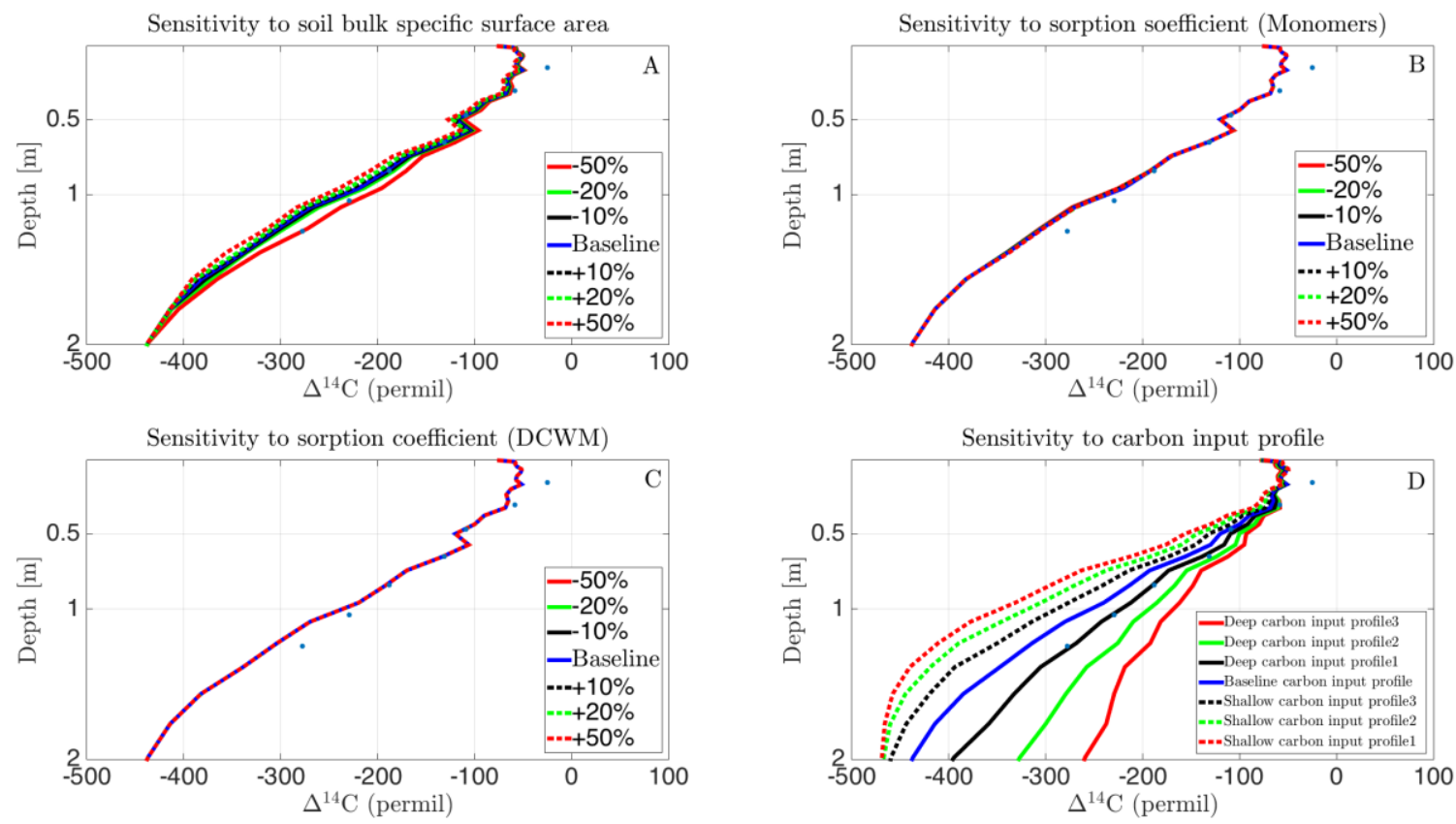

Figure 10. Sensitivity of $\Delta^{14} \mathrm{C}$ values of total SOM to changes in the (A) soil bulk specific surface area, (B) monomer sorption coefficients, (C) DCWM sorption coefficients, and (D) carbon input profiles. 